This is the final peer-reviewed accepted manuscript of

Ruiz, Karina B.; Rapparini, Francesca; Bertazza, Gianpaolo; Silva, Herman; Torrigiani, Patrizia; Biondi, Stefania: Comparing salt-induced responses at the transcript level in a salares and coastal-lowlands landrace of quinoa (Chenopodium quinoa Willd). ENVIRONMENTAL AND EXPERIMENTAL BOTANY 139. ISSN 0098-8472

DOI: 10.1016/j.envexpbot.2017.05.003

The final published version is available online at:

http://dx.doi.org/10.1016/j.envexpbot.2017.05.003

Rights / License: The terms and conditions for the reuse of this version of the manuscript are specified in the publishing policy. For all terms of use and more information see the publisher's website. 


\title{
Comparing salt-induced responses at the transcript level in a salares and coastal-lowlands landrace of quinoa (Chenopodium quinoa Willd)
}

\author{
Karina B. Ruiz ${ }^{\mathrm{a}, \mathrm{c}, 1, *}$, Francesca Rapparini ${ }^{\mathrm{b}, 1}$, Gianpaolo Bertazza ${ }^{\mathrm{b}}$, Herman Silva ${ }^{\mathrm{c}}$, \\ Patrizia Torrigiani ${ }^{\mathrm{d}}$, Stefania Biondi ${ }^{\mathrm{a}}$ \\ a Dipartimento di Scienze Biologiche, Geologiche e Ambientali, Università di Bologna, Via Imerio 42, 40126 Bologna, Italy \\ b IBIMET-CNR, via Gobetti 101, 40129 Bologna, Italy \\ 'Laboratorio de Genómica Funcional \& Bioinformática, Departamento de Producción Agrícola, Universidad de Chile, Av. Santa Rosa 11315, 8820808 La Pintana, \\ Santiago, Chile \\ ' Dipartimento di Scienze Agrarie, Università di Bologna, Viale Fanin 46, 40127 Bologna, Italy
}

\section{A R T I C L E I N F O}

Keywords:

Halophyte

Abscisic acid

Gene expression

Ion transporters

Polyamines

Quinoa

Salt stress

\begin{abstract}
A B S T R A C T
To further our understanding of the mechanisms governing salt stress responses and adaptation in halophytes, we explored morphological, metabolic, and gene expression responses to high salinity in quinoa (Chenopodium quinoa Willd). The main objective of this study was to analyze selected responsive genes in a time-course experiment to test for expression kinetics and to compare short-term salt-induced effects at the transcript level between two Chilean landraces belonging to different ecotypes. Quinoa genotypes exhibit a large variability in their responses to salinity, but it is not clear whether this is strictly related to the ecotype to which they belong. We tested this hypothesis by comparing the expression levels of genes involved in growth, ion homeostasis, abscisic acid (ABA) biosynthesis, perception, and conjugate cleavage, polyamine (PA) biosynthesis and oxidation, and proline biosynthesis as well as genes encoding ABA-dependent and independent transcription factors. Landraces R49 (salares ecotype) and Villarrica (VR, coastal-lowlands ecotype) were analyzed from 0.5 to $120 \mathrm{~h}$ after transfer to saline $(300 \mathrm{mM} \mathrm{NaCl})$ or non-saline (control) medium. All the genes, except CqSOS1 and CqNHX, were investigated here for the first time in quinoa under salt stress. Transcript levels were determined by quantitative Reverse Transcription-Polymerase Chain Reaction (qRT-PCR) analysis. Germination, seedling growth, ABA, and PA contents were evaluated in parallel. Even though on saline medium germination was inhibited in VR but not in R49, seedling growth reduction at $120 \mathrm{~h}$ was not substantially different in the two landraces. The ABA biosynthetic enzyme NCED was the most strongly salt-induced gene; ABA content was similarly enhanced (shoots) or unaffected (roots) in both R49 and VR. NaCl treatment also altered transcript levels of some PA metabolic enzymes and the PA profile leading to an enhanced ratio between the higher PAs and putrescine. All other genes also exhibited similar expression profiles in response to salinity in the two landraces especially in roots, while in shoots some differences were observed. Our results provide new information indicating that crucial salt adaptation strategies at the molecular level and in terms of ABA and PA contents are shared by the coastal-lowlands and salares landraces; however, the timing of the onset of transcriptional changes (e.g., NCED, ABF3, and RD22) may reflect genotype-dependent constitutive and/or inducible adaptive strategies.
\end{abstract}

\section{Introduction}

The conditions under which crops can be cultivated are strongly influenced by global climate change, in particular by increasing aridity and soil salinity. Sustainable agriculture adapted to a changing climate and an increasing world population must rely on the use of suitable crop species, or genotypes within species, resistant to abiotic stresses and with good nutritional properties (Ruiz et al., 2014). Quinoa (Chenopodium quinoa Willd) is the only halophytic crop species produ cing edible seeds with highly nutritious properties (Vega Gálvez et al., 2010; Ruiz et al., 2016b). The species' broad diversification in terms of native habitats accompanied by a high genetic diversity (Fuentes et al., 2009) has led to the identification of five ecotypes (Bazile et al., 2016). The salares ecotype is adapted to the extremely arid highland deserts in

\footnotetext{
* Corresponding author at: Dipartimento di Scienze Biologiche, Geologiche e Ambientali, Università di Bologna, Via Irnerio 42, 40126 Bologna, Italy.

E-mail address: kbruiz@gmail.com (K.B. Ruiz). 1
}

These authors contributed equally to the work. 
the Altiplano of the Andes (southern Bolivia, northern Chile, and northern Argentina). The coastal lowlands ecotype is found in central and southern Chile where it can grow at sea level; here annual rainfall ranges from 400 to $1,5002,000 \mathrm{~mm}$ and soils have a high water retention capacity. Strong differences in salt tolerance between quinoa varieties and landraces have been documented, both in terms of agronomic features and physiological responses (Adolf et al., 2012; Gómez Pando et al., 2010; Ruiz et al., 2016a).

The reduction in plant growth under salinity is due to two main stress factors, osmotic and ionic (Hanin et al., 2016; Yamamoto et al., 2015). Consequently, some of the most important physiological me chanisms of salt tolerance in both glycophytes and halophytes are to a large extent based on ion homeostasis. The latter is principally guaranteed by $\mathrm{Na}^{+}$exclusion via limited root uptake or exclusion from photosynthetically active organs or both (Taji et al., 2004), cytosolic $\mathrm{K}^{+}$ retention, and vacuolar $\mathrm{Na}^{+}$sequestration (Hanin et al., 2016), the latter being particularly important in halophytes that, different from glycophytes, achieve osmotic adjustment mainly through the accumulation, and not exclusion, of energetically inexpensive inorganic ions rather than low molecular weight organic solutes (Hariadi et al., 2011; Orsini et al., 2011; Bonales Alatorre et al., 2013). Thus, genes encoding transporters that mediate $\mathrm{Na}^{+}$and $\mathrm{K}^{+}$homeostasis, such as $\mathrm{NHX}$, Salt Overly Sensitive (SOS), and AKT are associated with salt tolerance (Apse and Blumwald, 2007; Albaladejo et al., 2017). In Antirrhinum majus, genes encoding cyclin dependent kinases, various transcription factors, and ion transport proteins, as well as genes involved in abscisic acid (ABA) and ethylene signaling pathways were also differentially expressed in response to $\mathrm{NaCl}$ (Trivellini et al., 2016).

The ABA response to salt stress is one of the first committed steps leading to adaptation, via activating specific pathways and modifying gene expression levels (Ismail et al., 2014), including the gene encoding the key enzyme in ABA biosynthesis 9 cis epoxycarotenoid dioxygenase (NCED) (Geng et al., 2013; Dong et al., 2015). The expression of genes encoding enzymes involved in the degradation of the conjugated forms of ABA is also regulated by ABA and environmental stresses, including high salinity (Dong et al., 2015). In particular, free ABA levels during dehydration and osmotic stress can be modulated by the hydrolytic activity of $\beta$ glucosidase homologues (AtBG1 and AtBG2) on inactive ABA glucose esters (ABA GE) (Lee et al., 2006). ABA signals are perceived by multiple cellular receptors. The predominant type of ABA receptors is the PYRABACTIN RESISTANT1 (PYR1)/REGULATORY COMPONENT OF ABA RECEPTOR (RCAR) localized in the cytosol and nucleus; PYR related genes, designated PYR like (PYLs), with varying affinities for ABA and other signalling components, have been identi fied (Finkelstein, 2013). Recently, phylogenetic analyses revealed that the $P Y R / P Y L / R C A R$ gene family was substantially expanded in the quinoa genome compared with other Amaranthaceae (Yasui et al., 2016). ABA BINDING FACTORS (ABFs) are basic leucine zipper (bZIP) domain transcription factors that bind ABA RESPONSIVE PROMOTER ELEMENTS (ABREs) in the promoters of ABA inducible genes (Dong et al., 2015). bZIP transcription factors are, therefore, involved in inducing downstream $\mathrm{ABA}$ responsive gene expression and are among the target proteins of ABA core signalling (Shinozaki and Yamaguchi Shinozaki, 2007). In Arabidopsis, the major cis acting elements that function in an ABA independent manner during abiotic stress responses are Dehydration Responsive Element (DRE)/C repeat (CRT; Finkelstein, 2013). Transcription factors that bind DRE and CRT elements are designated DRE binding proteins (DREBs) and CRT binding factor (CBF), respectively. DREB2 genes are involved in responses to drought and high salinity (Sun et al., 2015; Shavrukov et al., 2016). Induction of drought inducible Dehydration Responsive Protein genes are likewise mediated by ABA (e.g. RD22, RD26, RD29; Hanana et al., 2008; Nakashima et al., 2014).

The diamine putrescine (Put), and the higher polyamines (PAs) spermidine (Spd) and spermine (Spm), are important plant growth regulators involved in a wide range of biological processes (Kusano et al., 2008). PAs also play a major role in biotic and abiotic stress responses (Alcázar and Tiburcio, 2014). Under salt stress, they may function as osmolytes, scavenge stress generated ROS, promote antioxidant activities, and act as signaling molecules in hormonal pathways (e.g., ABA); they also regulate redox homeostasis, and ionic balance via regulating plasma membrane and tonoplast proton pumps, as well as $\mathrm{K}^{+}$and non selective cation channels, thereby improving vacuolar $\mathrm{Na}^{+}$ sequestration and cytosolic $\mathrm{K}^{+} / \mathrm{Na}^{+}$homeostasis (Minocha et al., 2014; Pottosin and Shabala, 2014; Pál et al., 2015; Saha et al., 2015). Ornithine decarboxylase (ODC) and arginine decarboxylase (ADC) directly or indirectly catalyze the biosynthesis of Put, while Spd and Spm are synthesized from Put via Spd synthase (SPDS), and Spm synthase (SPMS), respectively, by the addition of the amino propyl groups generated by $\mathrm{S}$ adenosylmethionine decarboxylase (SAMDC). Put and PAs are catabolized by diamine oxidase (DAO) and polyamine oxidase (PAO), respectively. PA biosynthetic genes, especially $A D C 2$, $S P D S 1$, and SPMS1, are major stress induced genes and their over expression in several crop species confers enhanced tolerance to abiotic stress (Alcázar and Tiburcio, 2014; Do et al., 2014). In Arabidopsis, $A t D A O$ gene expression is induced by wounding and involved in water balance homeostasis (Ghuge et al., 2015).

Genes likely to be involved in salinity tolerance, therefore, fall into three main functional categories: (1) those that regulate growth by controlling the rate of cell division (e.g., cyclin genes), expansion, and differentiation (2) those that control salt uptake, translocation, and compartmentalization; (3) those that have protective functions against environmental stresses (e.g. proline, PAs, ABA) (Munns, 2005). Although quinoa represents an interesting model species for studies on abiotic, in particular salt, stress responses (Ruiz et al., 2016b), genome wide transcriptomic analyses for the response to salinity have been performed in several halophytes (Song and Wang, 2015; Wang et al., 2015; Yamamoto et al., 2015), but not in quinoa. To date, only the ion homeostasis genes CqSOS1a and CqNHX were cloned and their expression levels analyzed under high salinity (Maughan et al., 2009; Ruiz Carrasco et al., 2011), but information regarding other genes implicated in salt stress responses is still lacking.

In this study, we compared two Chilean landraces of quinoa, one belonging to the salares ecotype (R49) and originating from the northern altiplano and another (Villarrica, VR) from a milder, rainier zone (coastal lowlands ecotype), based on the assumption that the former may be better adapted to salinity. A similar rationale has been used in several other studies aimed at comparing quinoa genotypes (Shabala et al., 2013; Bonales Alatorre et al., 2013; Bendevis et al., 2014; Ruiz et al., 2016a). Plant responses to salt stress and drought share a number of features and metabolic and signaling pathways (Golldack et al., 2014). Thus, based on genome wide transcriptomic analyses conducted in quinoa under drought stress (Morales et al., 2017; Raney et al., 2014) and on our earlier data regarding growth, biochemical, and molecular responses to salinity in Chilean landraces (Orsini et al., 2011; Ruiz Carrasco et al., 2011; Ruiz et al., 2016a), time course changes in the relative transcript abundance of the following genes were investigated from 0.5 to $120 \mathrm{~h}$ after transfer to saline medium: (i) genes involved in growth; (ii) ion homeostasis genes; (iii) PA biosynthetic, and oxidative genes, and (iv) a proline biosynthetic gene. Given the paucity of information on the salt induced ABA response in quinoa, we also investigated $\mathrm{ABA}$ biosynthetic, perception, and conjugate cleavage genes. Transcript levels of ABA responsive and other stress related transcription factors, were also evaluated. To determine how the predicted functions of $\mathrm{ABA}$ and PAs in the salt response corresponded to the temporal kinetics of genes encoding for biosynthesis and degradation enzymes, we quantified the levels of these growth regulators. 


\section{Materials and methods}

\subsection{Plant material}

Seeds of two quinoa (Chenopodium quinoa Willd) landraces, R49 (salares ecotype, northern Chile) and Villarrica (VR; coastal lowlands ecotype, southern Chile, $c a .100 \mathrm{~km}$ from the coast), obtained from the National Seed Bank of Chile managed by INIA Intihuasi (Vicuña, Chile), were surface sterilized with $70 \%(\mathrm{v} / \mathrm{v})$ ethanol for $5 \mathrm{~min}$ followed by $10 \%(\mathrm{v} / \mathrm{v})$ commercial bleach for $5 \mathrm{~min}$, and then rinsed five times in sterile water. After stratification at $4{ }^{\circ} \mathrm{C}$ for three days to synchronize germination, seeds were sown on $13.5 \mathrm{~cm}$ round Petri dishes containing autoclaved half strength MS medium (Murashige and Skoog, 1962) and $0.8 \%(w / v)$ Phytagel (Sigma Aldrich, Milano, Italy). Plates (20 per treatment and experiment) containing 1214 seeds each were then arranged vertically in growth chambers at $21 \pm 1{ }^{\circ} \mathrm{C}$ under a $16 / 8 \mathrm{~h}$ light/dark photoperiod (50 $\mu \mathrm{mol} \mathrm{m}^{2} \mathrm{~s}^{-1}$ irradiance). To determine salt effects on seed germination, seeds were sown directly on media containing (or not) $300 \mathrm{mM} \mathrm{NaCl}$; percentage germination was mea sured at regular intervals up to 8 days after sowing. For growth measurements, gene expression analysis, and PA and ABA determina tions, seedlings were transferred, five days after sowing on non saline medium, to Petri dishes containing the same medium added or not (controls) with $300 \mathrm{mM} \mathrm{NaCl}$. Root and shoot elongation growth after transfer was measured by marking the position of the tip of each organ at $0 \mathrm{~h}$ and again at 5 and 12 days after transfer; the number of lateral roots, and the angle between the youngest lateral root (closest to the tip) and the main root were measured using the ImageJ software (Abràmoff et al, 2004). Lateral root density was calculated as the number of laterals per mm primary root length. Twelve days after transfer, the remaining plants were harvested and root and shoot fresh and dry (after freeze drying) biomass determined.

For biochemical and molecular analyses, seedlings transferred to media containing 0 or $300 \mathrm{mM} \mathrm{NaCl}$ were collected at $0,0.5,2,24$ and $120 \mathrm{~h}$ after transfer. At each time point, samples of roots and shoots were collected separately; some samples were immediately used for RNA extraction while others were pooled, freeze dried, and stored at $-20^{\circ} \mathrm{C}$ for polyamine and $\mathrm{ABA}$ determinations. The experiments were repeated at least eight times and samples from the same treatment and time point were pooled.

\subsection{Real time quanritarive Reverse Transcription Polymerase Chain Reaction (RT qPCR)}

Total RNA was extracted from roots and shoots (three separate extractions of $0.1 \mathrm{~g}$ FW each) according to Chang et al. (1993). RNA yield and purity were checked by means of UV absorption spectra, whereas RNA integrity was determined by electrophoresis on agarose gel. DNA was removed using the TURBO DNA free ${ }^{\text {mw }}$ (Applied Biosys tems, Califomia, USA) from $3 \mu g$ aliquots of total RNA. The first strand cDNA was synthesized from $2 \mu \mathrm{g}$ of the DNase treated RNA by means of the High Capacity cDNA Kit (Applied Biosystems) using random primers. The reaction mixture for the $\mathrm{qRT}$ PCR analysis was made in a final volume of $25 \mu \mathrm{L}$ containing $3 \mathrm{ng}$ of cDNA, $5 \mathrm{pmol}$ of each primer, and $12.5 \mu \mathrm{L}$ of the Fast SYBR Green PCR master mix (Applied Biosystems) according to the manufacturer's instructions. Elongation Factor1a (CqEF1a) was used as reference gene (Sudhakar Reddy et al., 2016) to normalize and estimate up or down regulation of the target genes for all qRT PCR analyses. Sequences of genes coding for transcription factors were obtained from RARTF (http://rarge.psc. riken.jp/rartf/) and DATF (http://datf.cbi.pku.edu.cn/) databases and compared with those of the quinoa drought RNA seq database (Morales et al., 2017). Sequences for other salinity related genes were obtained from the same quinoa RNA seq database (http://www.ncbi.nlm.nih. gov/bioproject/305752) and the NCBI database. Primer sequences for ABA related, (NCED, PYL, PYR, BG1, ABF3), polyamine related ( $A D C 1$,
$A D C 2, S A M D C, S P D S 1, S P M S, D A O$ ), and ion homeostasis related (CqNHX, CqSOS1a, HKT) genes as well as CycD3, $\beta E X P 1, D R E B 2 a$, bZIP24, and RD22 are listed in Table S1 in the online version at DOI: http://dx.doi.org/10.1016/j.envexpbot.2017.05.003 (Supplementary material). PCRs were carried out with StepOnePlus ${ }^{R M} 7500$ Fast (Applied Biosystems) for $30 \mathrm{sec}$ at $95^{\circ} \mathrm{C}$ and then for 40 cycles as follows: $95^{\circ} \mathrm{C}$ for

$3 \mathrm{~s}, 60^{\circ} \mathrm{C}$ for $30 \mathrm{~s}$.Expression levels are the mean normalized expression (MNE) values of the triplicates, calculated according to equation 2 of the $\mathrm{Q}$ gene software (Muller et al, 2002). Data are presented as fold changes in salt treated versus control samples, except in Fig. 8 and Fig. S1 in the online version at DOI: http://dx.doi.org/10.1016/ j.envexpbot 2017.05.003.

\subsection{Gas chromatography mass spectrometry (GC MS) analysis of $A B A$}

A highly reproducible extraction procedure without additional time consuming purification steps was adapted from Müller and Munné Bosch, 2011 allowing rapid and sensitive ABA determination from minimal amounts of plant tissue. Approximately $20 \mathrm{mg}$ DW of freeze dried shoots and roots were ground in liquid nitrogen in a $2 \mathrm{ml}$ Eppendorf tube, and then extracted ovemight at $4{ }^{\circ} \mathrm{C}$ with $1 \mathrm{~mL}$ of cold extraction solvent (isopropanol: glacial acetic acid; 99:1) to which $100 \mathrm{ng}$ of $\left[{ }^{2} \mathrm{H}_{4}\right] \mathrm{ABA}$ (OlChemIm Ltd., Czech Republic) were added as internal standard for quantitative mass spectral analysis. After centri fugation $(10,000 \mathrm{rpm}$ for $10 \mathrm{~min}$ at $4{ }^{\circ} \mathrm{C}$ ), the supernatant was collected and the pellet was re extracted with $0.5 \mathrm{~mL}$ of extraction solvent and the extraction repeated twice. Supernatants were combined and dried completely under a nitrogen stream and re dissolved in $300 \mu \mathrm{L}$ of methanol for methylation with diazomethane according to Cohen, 1984. The samples were evaporated to dryness and then taken up in $20 \mu \mathrm{L}$ ethyl acetate before injection into an Agilent $7890 \mathrm{~N}$ series gas chromatograph connected to a mass spectrometer equipped with a selective detector (Agilent 5975, Palo Alto, CA, USA). For the analysis, $2 \mu \mathrm{L}$ of the methylated sample was injected in the splitless mode into a HP 1MS capillary column $(60 \mathrm{~m} \times 0.25 \mathrm{~mm}, 0.25 \mu \mathrm{m}$ film thickness, Agilent, Palo Alto, CA, USA) using $\mathrm{He}$ carrier gas at $1.5 \mathrm{~mL} \mathrm{~min}{ }^{-1}$. Injector temperature was $270{ }^{\circ} \mathrm{C}$ and the temperature programme was $90{ }^{\circ} \mathrm{C}$ for 5 min, followed by an increase of $20^{\circ} \mathrm{C} \mathrm{min}^{-1}$ to $180^{\circ} \mathrm{C}, 5^{\circ} \mathrm{C} \mathrm{min}{ }^{-1}$ to $220^{\circ}$ $\mathrm{C}, 10^{\circ} \mathrm{C} \mathrm{min}{ }^{-1}$ to $280^{\circ} \mathrm{C}$, then $8 \mathrm{~min}$ isothermically at $280^{\circ} \mathrm{C}$. The mass detector was set on the electronic impact (El) mode at $70 \mathrm{eV}$, transfer line temperature was $280{ }^{\circ} \mathrm{C}$. ABA was determined using the Selected Ion Monitoring (SIM) mode from ions at $m / z 162,166,190$, and 194; ABA concentrations were calculated on the basis of $m / z 190 / 194$ using the isotope dilution equation described by Cohen et al., 1986.

\subsection{HPLC polyanine derrmination}

Polyamine analyses were performed on freeze dried root and shoots. The samples (about $0.02 \mathrm{~g} \mathrm{DW}$ ) were homogenized in $10 \mathrm{vols}$ of $4 \%$ ( $v / v)$ cold perchloric acid and centrifuged at $14,000 \times g$ for $30 \mathrm{~min}$ at $4{ }^{\circ} \mathrm{C}$. Aliquots $(200 \mu \mathrm{L})$ of the supernatants and standard solutions of putrescine (Put), spermidine (Spd), and spermine (Spm) were deriva tized with dansyl chloride (Scaramagli et al, 1999). Dansylated derivatives were extracted with toluene, taken to dryness and resus pended in acetonitrile. PAs were separated and quantified by HPLC using a reverse phase $C 18$ column (Spherisorb ODS2, $5 \mu \mathrm{m}$ particle diameter, $4.6 \times 250 \mathrm{~mm}$, Waters, Wexford, Ireland) and a programmed acetonitrile/water step gradient (flow rate, $1 \mathrm{~mL} \mathrm{min-1)}$ on a Jasco system (Jasco Corp., Tokyo, Japan) consisting of a PU 1580 pump, an LG 158002 ternary gradient unit, a DG 158053 three line degasser, and a FP 1529 fluorescence detector, linked to an autosampler (AS 2055 Plus). 
$\rightarrow$ R49 C $\rightarrow$ R49T $\diamond-V R C \rightarrow V R T$
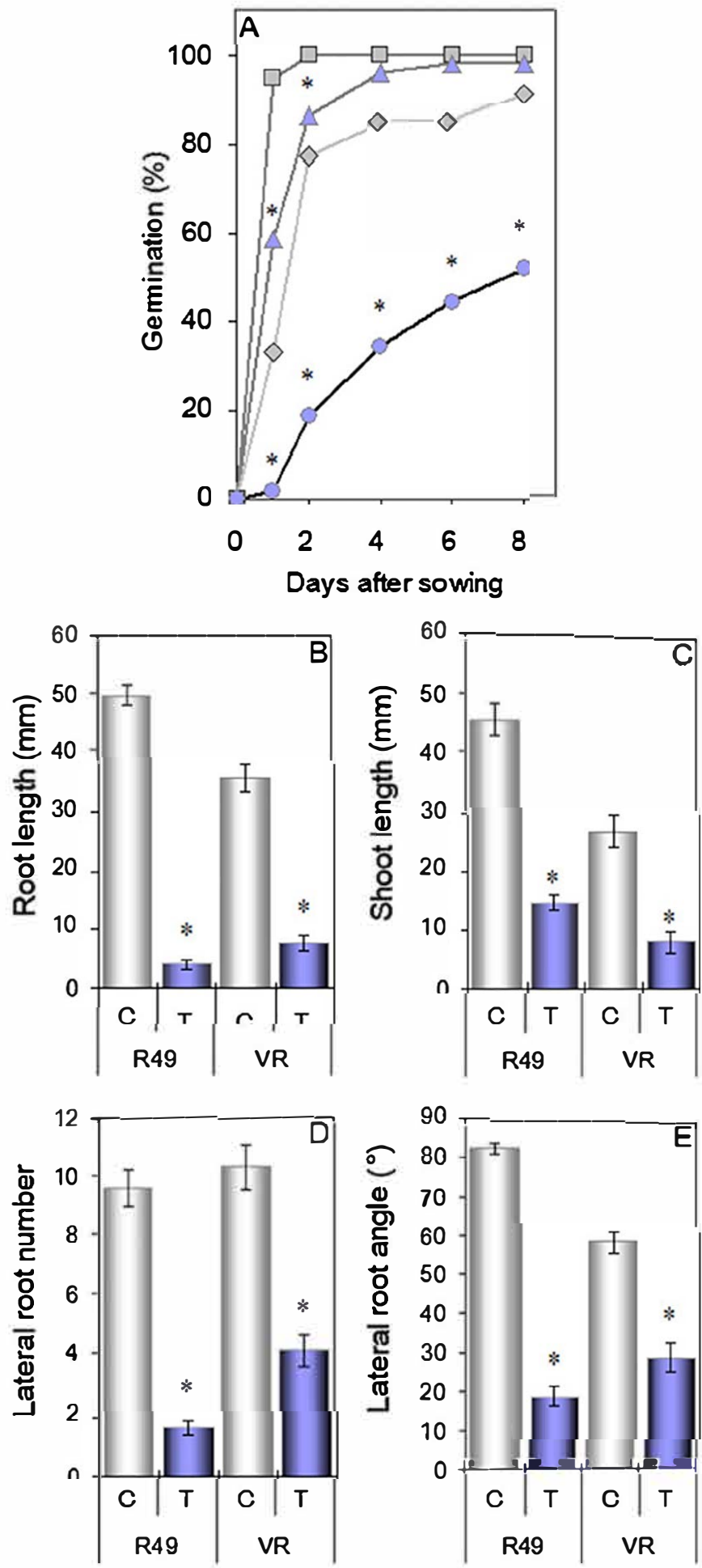

Fig. 1. Percent germination of R49 and VR seeds sown directly on control (C) or saline medium containing $300 \mathrm{mM} \mathrm{NaCl}$ (T) at 2, 4,6, and 8 days after sowing (A). Root length (B), shoot length (C), number of lateral roots (D), and angle between the youngest lateral root and the primary root (E) in R49 and VR seedlings 5 days after transfer to non-saline (C) and saline (T) medium. Bars represent the SE and asterisks indicate significant dlfferences $(P<0.05$ ) between control and salt-treated samples within the same landrace; $\mathrm{n}=120$.

\subsection{Statistical analyses}

Data from qRT PCR, PA, and ABA analyses represent the means \pm SE. Significant differences between (i) control and salt treatment within a landrace for a single time point, and (ii) between landraces were tested by Tukey's honestly significant difference (HSD) post hoc test for multiple comparisons when the one way analysis of variance (ANOVA) indicated significant differences $(P<0.05)$ using the SAS 9.3 (SAS Institute, Cary NC, USA) software.

\section{Results}

\subsection{Gennination, seedling growth, and root architecture}

R49 seeds germinated more quickly than those of VR, but, by day 8 , percent germination reached 90100 in both landraces (Fig. 1A). Germination on saline medium 8 days after sowing was reduced, by ca. $40 \%$ relative to controls, only in VR (Fig. 1A).

Under control conditions, VR roots and shoots were shorter than those of R49 ( $<0.05$; Fig. 1B, C). Five days after transfer (DAT), salt strongly inhibited root growth in R49 (92\%) and slightly less in VR (79\%); shoot length was also significantly reduced by salt in both landraces (ca. 70\%; Fig. 1B, C). The salt induced reduction in the number of lateral roots was also strong in $\mathrm{R} 49$ (83\% inhibition relative to controls) and less marked in VR (60\%, Fig. 1D). The angle between the primary root and the youngest lateral root was reduced by $300 \mathrm{mM}$ $\mathrm{NaCl}$ to about one fourth and one half of control values in R49 and VR, respectively (Fig. 1E). At 12 DAT the root to shoot FW ratio was higher (1.4) in VR than (0.5) in R49 likely due to higher lateral root density ( 0.60 versus 0.22 ), and declined considerably (by $6070 \%$ ) on saline medium in both landraces, while the root to shoot DW ratio increased slightly or remained unaffected by salt (data not shown). From 5 DAT to 12 DAT, root length increased three and two fold, the number of lateral roots by 3.8 and 3.3 times, and shoot length by only $50 \%$ and $0 \%$ in R49 and VR, respectively (datanot shown).

\subsection{Basal gene expression at $0 \mathrm{~h}$}

The basal levels of transcript abundance measured at the time of transfer $(0 \mathrm{~h})$ for all the considered genes are shown in Fig. S1 in the online version at DOI: http://dx.doi.org/10.1016/j.envexpbot.2017.05. 003. In both R49 and VR, ADC1 and SPDS1 were the most highly expressed genes in both roots and shoot, and expression was much higher in the latter than in the former. The transcript accumulation of $A D C 1$ was two fold higher in shoots of R49 than VR, while at the root level no differences were observed. The genes with the lowest expression levels were $\beta E X P 1, H K T, A D C 2, O D C, D A O, P A O$, and SPMS. RD22 transcript levels were two to several fold higher (shoots and roots, respectively) in VR than in R49. The expression of DREB2a was also higher in roots of VR.

\subsection{Growth related gene expression}

In roots of R49, CycD3 transcript amount was significantly reduced by salt starting from $0.5 \mathrm{~h}$ but gradually returned to control values at $120 \mathrm{~h}$ (Fig. 2A); in shoot this down regulation was observed only at the end of the experiment ( $120 \mathrm{~h}$; Fig. 2B). In VR shoots, the down regulation at $120 \mathrm{~h}$ was stronger than in R49 (ca. 9 fold us 3 fold, Fig. 2A).

$\beta$ EXP1 transcript amounts in salt treated roots increased dramatically at $120 \mathrm{~h}$ both in R49 and, to a lesser extent but already from $0.5 \mathrm{~h}$, in VR (Fig. 2A). In shoots, no effect or slight down regulation was observed in response to salt in R49, while in VR the early up regulation was followed by a strong (up to eight fold) down regulation at 2 and 24 h (Fig. 2B).

\subsection{Ion homeostasis genes}

In roots of R49 and VR, CqNHX expression was significantly induced by salt only at $24 \mathrm{~h}$ (Fig. $3 \mathrm{~A}$ ). In shoots, salt did not significantly affect 


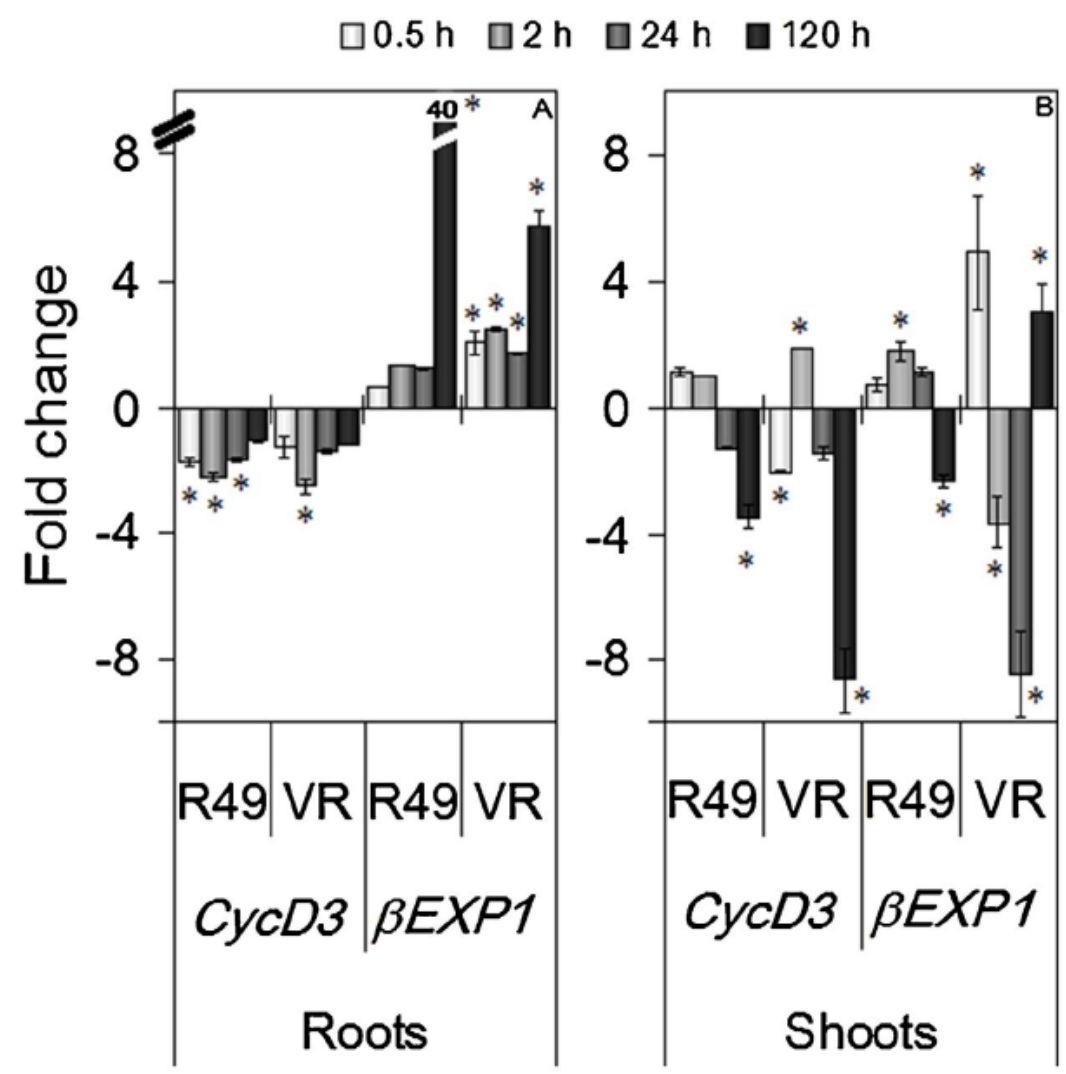

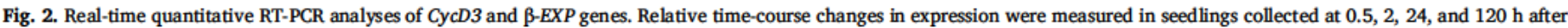

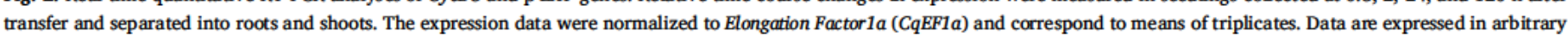

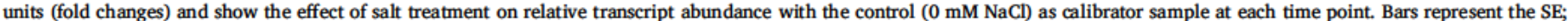
asterisks indicate significant differences $(\mathrm{P}<0.05)$ relative to the control within each genotype and for each time point.

CqNHX transcript level in R49, but increased it at $120 \mathrm{~h}$ in VR (Fig. 3B). HKT expression levels (MNE) were $c a$. two orders of magnitude lower than those of other ion transporter genes both under saline and non saline conditions (data not shown). In R49, the gene was up regulated by salt only at $2 \mathrm{~h}$ in both roots and shoots, while in VR only in shoots and only at $120 \mathrm{~h}$ (Fig. 3A, B). CqSOS1a transcript was significantly up regulated only in VR, again only at $120 \mathrm{~h}$ in roots and transiently $(24 \mathrm{~h})$ in shoots (Fig. 3A, B).

\subsection{Transcription factors and stress related genes}

In R49 the strongest increase in DREB2a transcript amount occurred at $2 \mathrm{~h}$ and expression declined with time, while in VR the response was strongest at $0.5 \mathrm{~h}$ in both organs (Fig. 4A, B). The amount of bZIP24

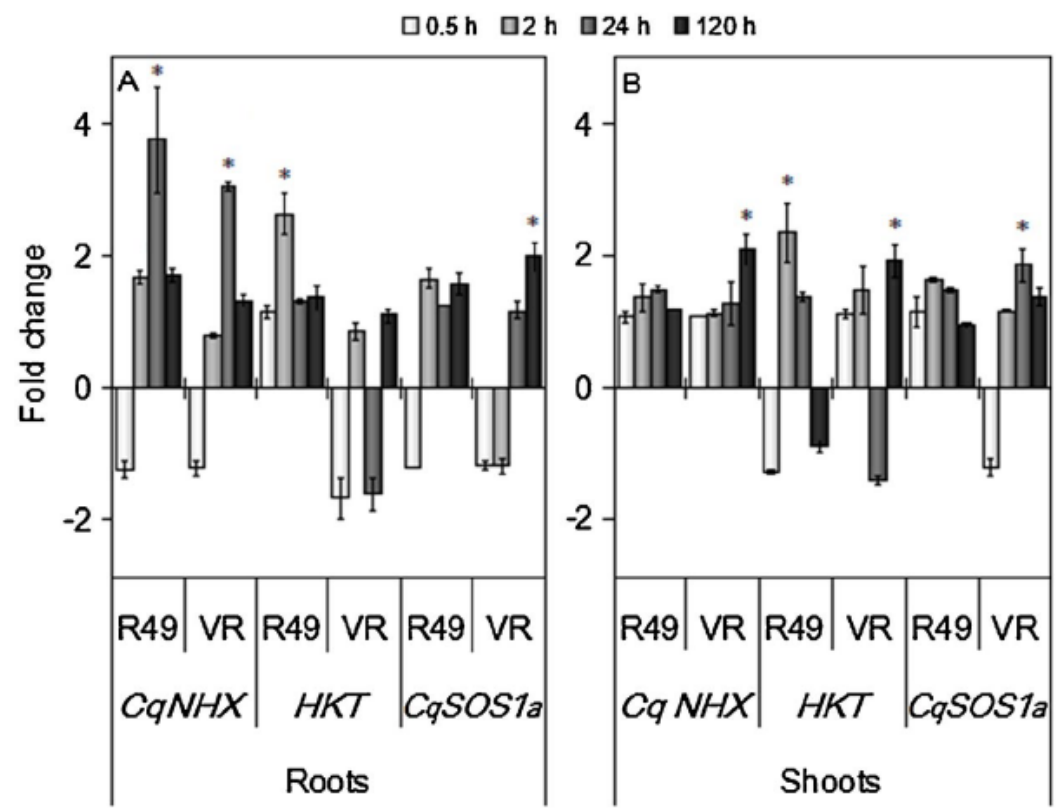

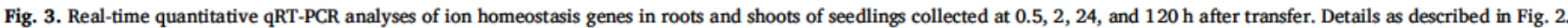




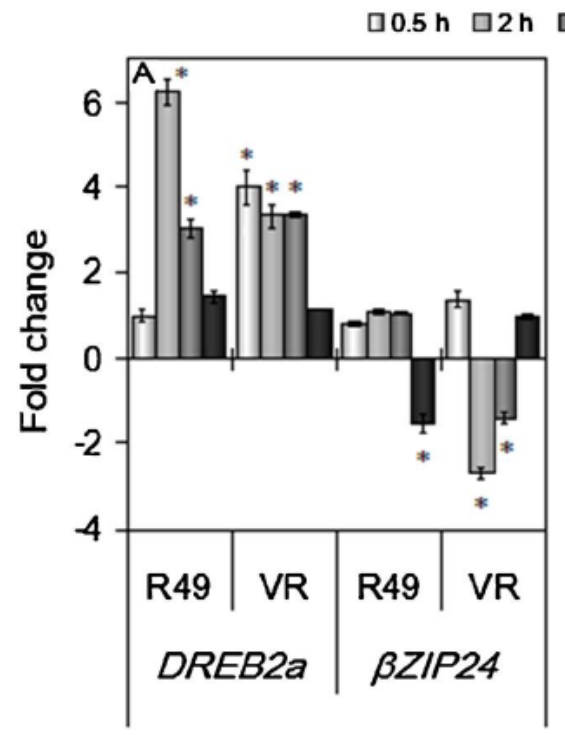

$\square 24 \mathrm{~h} \square 120 \mathrm{~h}$
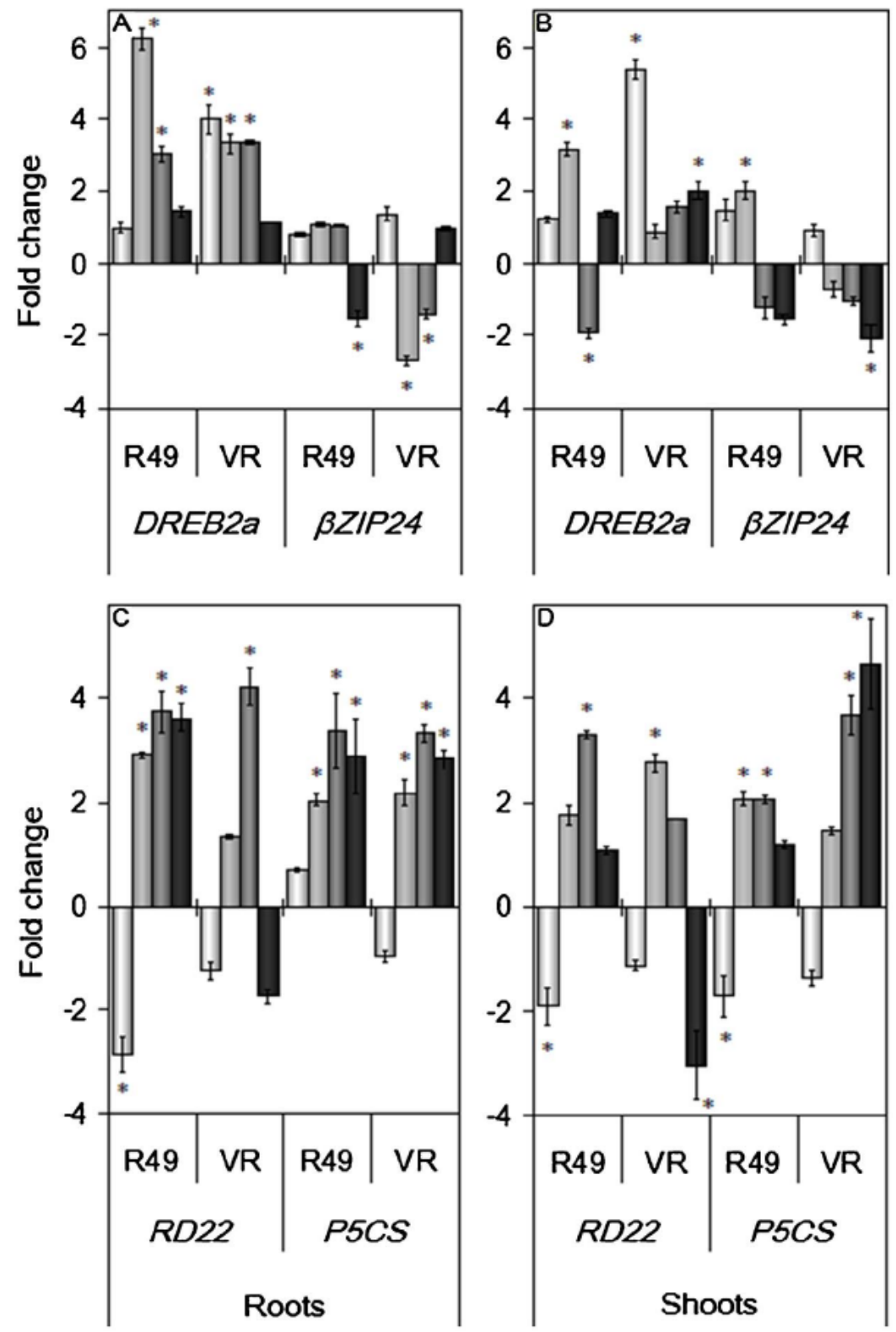

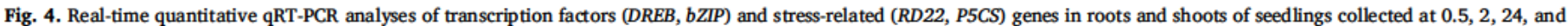
$120 \mathrm{~h}$ after transfer. Details as described in Fig. 2.
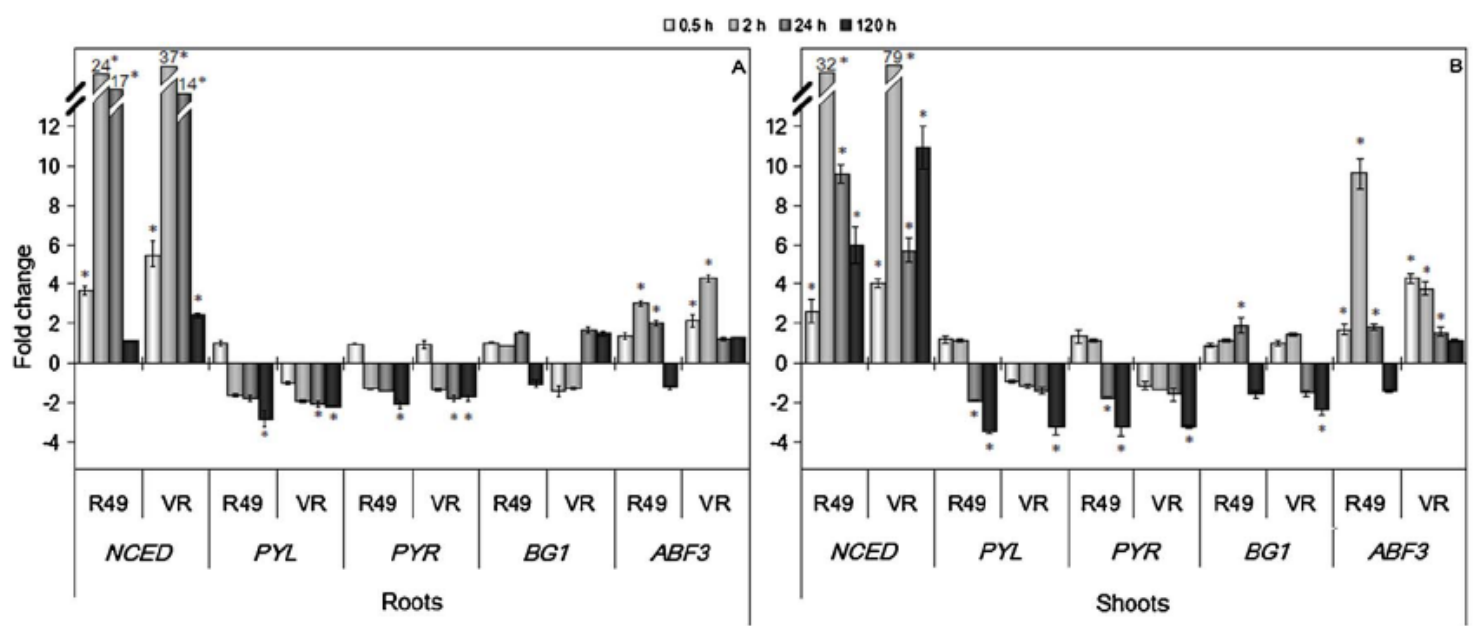

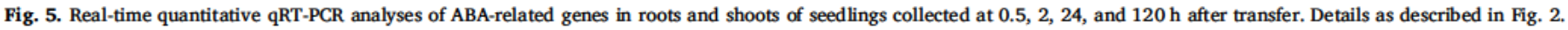


transcript was scarcely affected by salinity or even slightly down regulated in both landraces (Fig. 4A, B). RD22 gene expression in salt treated plants was initially $(0.5 \mathrm{~h})$ down regulated in both roots and shoots of both landraces but then increased above control levels, especially in roots ( $c a$. four fold at $24 \mathrm{~h}$ ); in R49 transcripts remained high up to $120 \mathrm{~h}$ whereas in VR they declined below controls. In shoots a maximum $c a$. three fold increase of $R D 22$ transcript above control levels occurred, at $2 \mathrm{~h}$ in VR, at $24 \mathrm{~h}$ in R49 (Fig. 4C, D). In R49 and VR, transcript levels of the proline biosynthetic gene P5CS were enhanced (up to four fold) by salt in both organs starting from $2 \mathrm{~h}$ and up to $120 \mathrm{~h}$ (Fig. 4C, D), when however the stronger response of VR shoots was evident.

\section{6. $A B A$ related gene expression and $A B A$ content}

In both landraces, NCED was rapidly $(0.5 \mathrm{~h})$ up regulated under saline conditions and reached maximum transcript levels at $2 \mathrm{~h}$ after transfer. In VR these increases relative to their respective controls were stronger than in R49: 37 vs 24 fold in roots, and 79 vs 32 fold in shoots; NCED transcript abundance stayed well above control levels at $24 \mathrm{~h}$ and then declined (Fig. 5A, B). PYL and PYR genes in salt stressed organs were, instead, both slightly down regulated starting from 2 or $24 \mathrm{~h}$, with maximum decrease at $120 \mathrm{~h}$ in both landraces (Fig. 5A, B). BG1 expression was slightly up regulated in R49 shoots and late down regulated in VR shoots (Fig. 5A, B). Under saline conditions, transcript levels of $A B F 3$ were significantly increased in both organs relative to controls, starting from $0.5 \mathrm{~h}$ in both landraces, reaching maximum abundance at $2 \mathrm{~h}$ (four to nine fold control levels in R49), and then declined (Fig. 5A, B).

ABA concentrations in shoots of R49 and VR at the time of transfer ( 0 h) were ca. $0.5 \mathrm{nmol} \mathrm{g}^{-1} \mathrm{DW}$, whereas in roots VR had a significantly (P $<0.05$ ) higher amount of ABA than R49 (ca. $0.7 v s 1.7 \mathrm{nmol} \mathrm{g}^{-1} \mathrm{DW}$, respectively). In both landraces, $\mathrm{ABA}$ levels increased significantly in salt treated shoots as compared with controls by two to three fold starting from $2 \mathrm{~h}$ after transfer and maintained up to $120 \mathrm{~h}$; no significant changes were induced by salt treatment in roots of either landrace (Table 1).

\subsection{Put related gene expression and Put content}

Under saline conditions, $A D C 1$ transcripts were either unaffected (R49) or tended to decrease (VR) in roots, whereas the gene was transiently $(2 \mathrm{~h})$ slightly up regulated in shoots of both landraces (Fig. $6 \mathrm{~A}, \mathrm{~B})$. On the contrary, the $A D C 2$ message was enhanced by salt at 24 and/or $120 \mathrm{~h}$ in roots of both R49 and VR (up to four fold) while in shoots, it was transiently up regulated at $2 \mathrm{~h}$, in both landraces (Fig. 6A, B). The low expression level of $O D C$ was not affected by salinity in either organ (data not shown). Conversely, DAO transcript abundance in roots was enhanced by salt at 2 and $24 \mathrm{~h}$ in both R 49 and
VR, but not in shoots, where strong up regulation (ca. seven fold) was observed only in VR at $2 \mathrm{~h}$ (Fig. 6A, B).

Put levels in control roots were generally lower than in shoots and comparable for both landraces; in shoots, the highest Put content was observed at the time of transfer $(0 \mathrm{~h})$. In R49 roots, Put increased 24 and $120 \mathrm{~h}$ after transfer to non saline medium whereas it declined significantly (by ca. $60100 \%$ ) on saline medium relative to controls (Fig. 7A). In R49 control shoots, Put also increased over time, but was significantly lower ( $c a$. half) in salt treated shoots than in control ones at $120 \mathrm{~h}$ (Fig. 7A, B). In VR, Put levels in roots and shoots were not significantly affected by salt, except at $120 \mathrm{~h}$ when they declined by about half (Fig. 7A, B).

\subsection{Spd and Spm related gene expression and PA contents}

SAMDC transcripts in the roots of both genotypes were not significantly affected by salt; in shoots, there was a strong salt induced down regulation in R49 at $120 \mathrm{~h}$ while in VR it occurred very early ( 0.5 h) (Fig. 6C, D).

SPDS1 transcript amount was not substantially affected in salt treated roots and shoots of R49 relative to controls (Fig. 6C); in VR, the gene was transiently up regulated by salt in roots $(24 \mathrm{~h})$ and shoots $(120$ h) (Fig. 6C, D). SPMS gene expression was transiently up regulated (24 h) in roots of both landraces; in shoots, transcript levels were increased starting from $2 \mathrm{~h}$ after transfer to saline medium, but only in VR (Fig. 6C, D). No major salt induced changes in Spd levels were observed in R49, but a significant increase was observed in VR at $120 \mathrm{~h}$ in both organs (Fig. 7C, D). In R49, Spm content was enhanced by salt starting from $2 \mathrm{~h}$ in roots (ca. 3.5 fold) and from $24 \mathrm{~h}$ in shoots. After a transient decline, Spm content in VR returned to control levels in salt treated roots, while in shoots it increased relative to controls after $24 \mathrm{~h}$, with the strongest change ( 4.5 fold) at $120 \mathrm{~h}$ (Fig. 7E, F).

The (Spd $+\mathrm{Spm}) /$ Put ratios ranged from 0.05 to 0.5 under control conditions, depending on the organ and the landrace; they increased in R49 (both organs) under saline conditions relative to controls at all time points (up to a maximum of 3.5 fold), whereas in VR this increase was observed only at $120 \mathrm{~h}$ and was 2.8 fold in roots, and 9.5 fold in shoots (data not shown).

\subsection{Major salt responsive genes and their expression pattern during saline treatment}

Ten genes whose transcript levels were most strongly altered under saline as compared with non saline conditions were selected to draw up a heatmap of their time course changes in MNE under salinity (Fig. 8). In roots, NCED was the most highly expressed gene in both landraces, with maximum expression occurring early (at $0.5 / 2 \mathrm{~h}$ ). The expression profiles of $A B F 3$ and DREB2a reflected that of NCED; all three exhibited highest expression at $0.5 \mathrm{~h}$ in VR and at $2 \mathrm{~h}$ in R49. RD22 was generally

Table 1

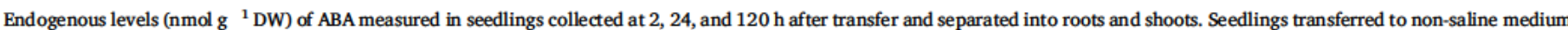

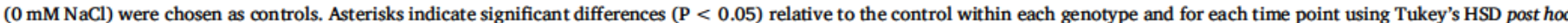
test. Values are means \pm standard error of $n=3-5$.

\begin{tabular}{|c|c|c|c|c|c|}
\hline \multirow[t]{2}{*}{ Genotype } & \multirow[t]{2}{*}{ Time (h) } & \multicolumn{2}{|l|}{ Roots } & \multicolumn{2}{|l|}{ Shoots } \\
\hline & & $\mathrm{C}$ & $\mathrm{s}$ & $\mathrm{C}$ & $\mathrm{s}$ \\
\hline \multirow[t]{4}{*}{ R49 } & 0 & $0.55 \pm 0.04$ & - & $0.52 \pm 0.05$ & - \\
\hline & 2 & $0.89 \pm 1.15$ & $0.93 \pm 0.22$ & $0.57 \pm 0.07$ & $1.29 \pm 0.09^{*}$ \\
\hline & 24 & $0.58 \pm 0.05$ & $0.77 \pm 0.08$ & $0.97 \pm 0.15$ & $3.30 \pm 0.46^{*}$ \\
\hline & 120 & $0.83 \pm 0.03$ & $0.64 \pm 0.09$ & $1.14 \pm 0.10$ & $2.11 \pm 0.24 *$ \\
\hline \multirow[t]{4}{*}{ VR } & 0 & $1.95 \pm 0.31$ & - & $0.63 \pm 0.16$ & - \\
\hline & 2 & $1.51 \pm 0.39$ & $1.29 \pm 0.22$ & $0.79 \pm 0.05$ & $1.96 \pm 0.32$ * \\
\hline & 24 & $1.47 \pm 0.19$ & $1.63 \pm 0.24$ & $0.83 \pm 0.04$ & $2.78 \pm 0.18^{*}$ \\
\hline & 120 & $1.75 \pm 0.30$ & $1.59 \pm 0.38$ & $1.03 \pm 0.23$ & $1.85 \pm 0.50$ * \\
\hline
\end{tabular}



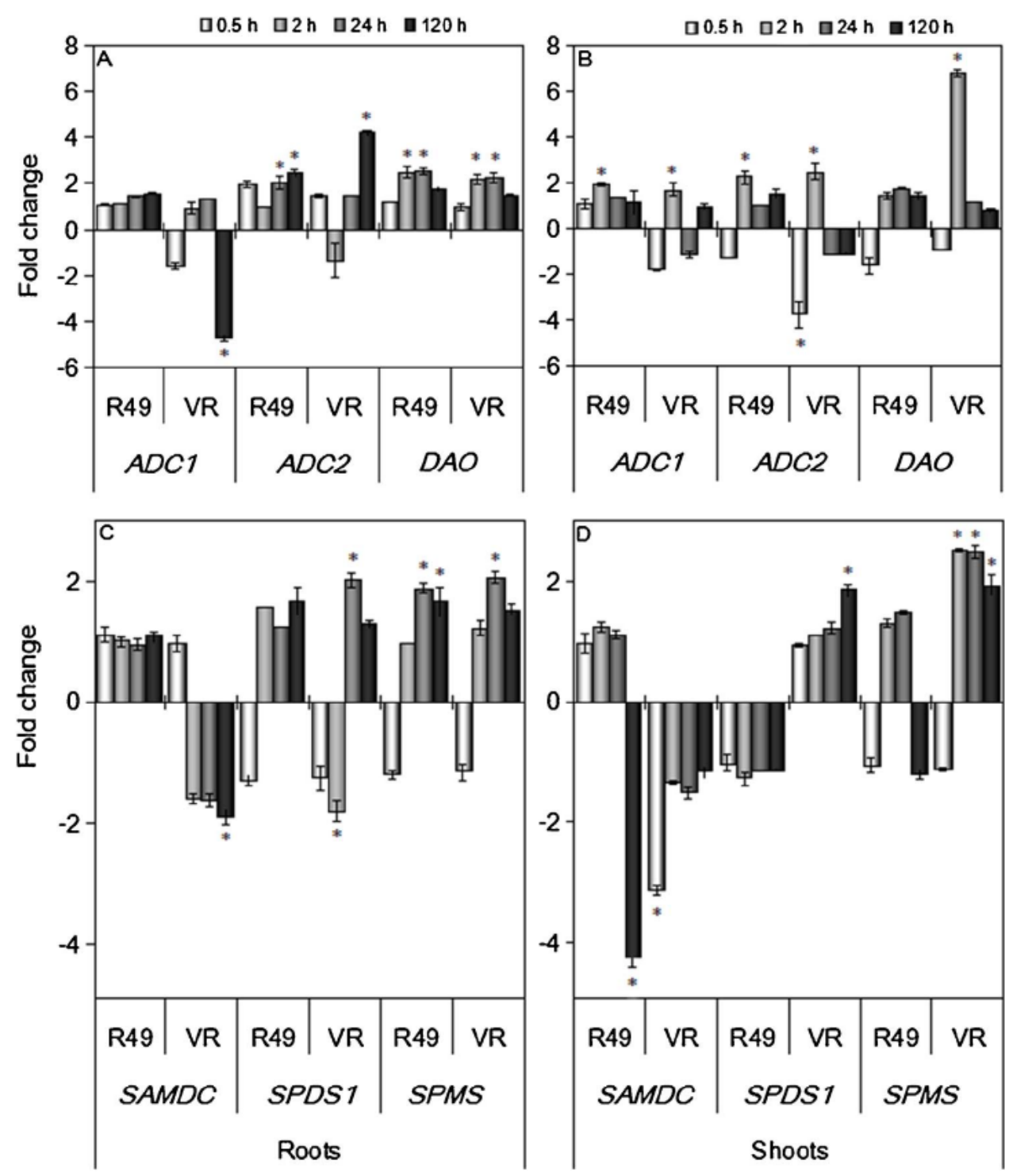

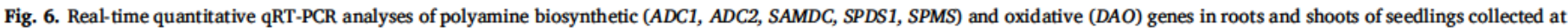
$0.5,2,24$, and $120 \mathrm{~h}$ after transfer. Details as described in Fig. 2.

more highly expressed in VR and very early after transfer to saline medium. CqNHX expression levels were comparable in the two land races and increased with time with maximum expression at $24 \mathrm{~h}$. In both landraces P5CS was also a highly expressed gene (VR > R49) especially at $24120 \mathrm{~h}$ as was $A D C 2$. In shoots, NCED displayed a similar pattern as in roots. The highest NCED, ABF3 and DREB2a expression always occurred earlier in VR $(0.5 \mathrm{~h})$ than in R49. In R49, $R D 22$ transcript levels were more uniform over time as compared with roots while in VR it was one of the most highly expressed genes with a peak at $2 \mathrm{~h}$. P5CS expression was relatively high as compared with other genes starting from $2 \mathrm{~h}$ in VR; in R49 it was stable over time. $C q N H X$ and $A D C 2$ expression was low and did not change during exposure to salt. In both organs, DAO, SPMS, and PYL transcript levels were low and stable over time.

\section{Discussion}

\subsection{Morphological responses and expression patterns of CycD3 and $\beta$ EXP1}

The seedling transfer procedure allowed us to discriminate between the effects of salinity on germination and on seedling growth. The higher percentage seed germination on saline medium in R49 than in
VR suggests that this parameter may represent a salt tolerance trait associated with the salares landrace. Tolerance to salt at the germina tion stage is often independent of tolerance during the seedling stage as the two processes are probably controlled by different mechanisms (Gómez Pando et al., 2010). In our study too, seedling growth on saline medium did not follow the same pattern as germination since it was reduced to a similar extent in the two landraces; however, specific parameters (e.g., root versus shoot growth) were differentially affected in R49 and VR as already reported in other quinoa genotypes (Gómez Pando et al., 2010; Adolf et al., 2013). Even though some defense related biochemical features may reflect the higher salt tolerance of R49 compared to coastal lowlands landraces (e.g., VR), lack of better growth performance of R49 suggested a trade off between growth and stress adaptation also in adult pot grown plants (Ruiz et al., 2016a). Reduction of plant biomass is a common response to salt also in halophytes. In particular, the dramatic changes in the root to shoot FW ratio of VR and R49 confirm previous results for pot grown quinoa plants showing a salt induced reduction in total plant biomass mainly due to decreased root DW; a negative correlation between root $\mathrm{Na}^{+}$concentration and total biomass was reported (Ruiz et al., 2016a). Interestingly, the angle between lateral roots and the primary root, examined here for the first time in quinoa, also declined significantly 

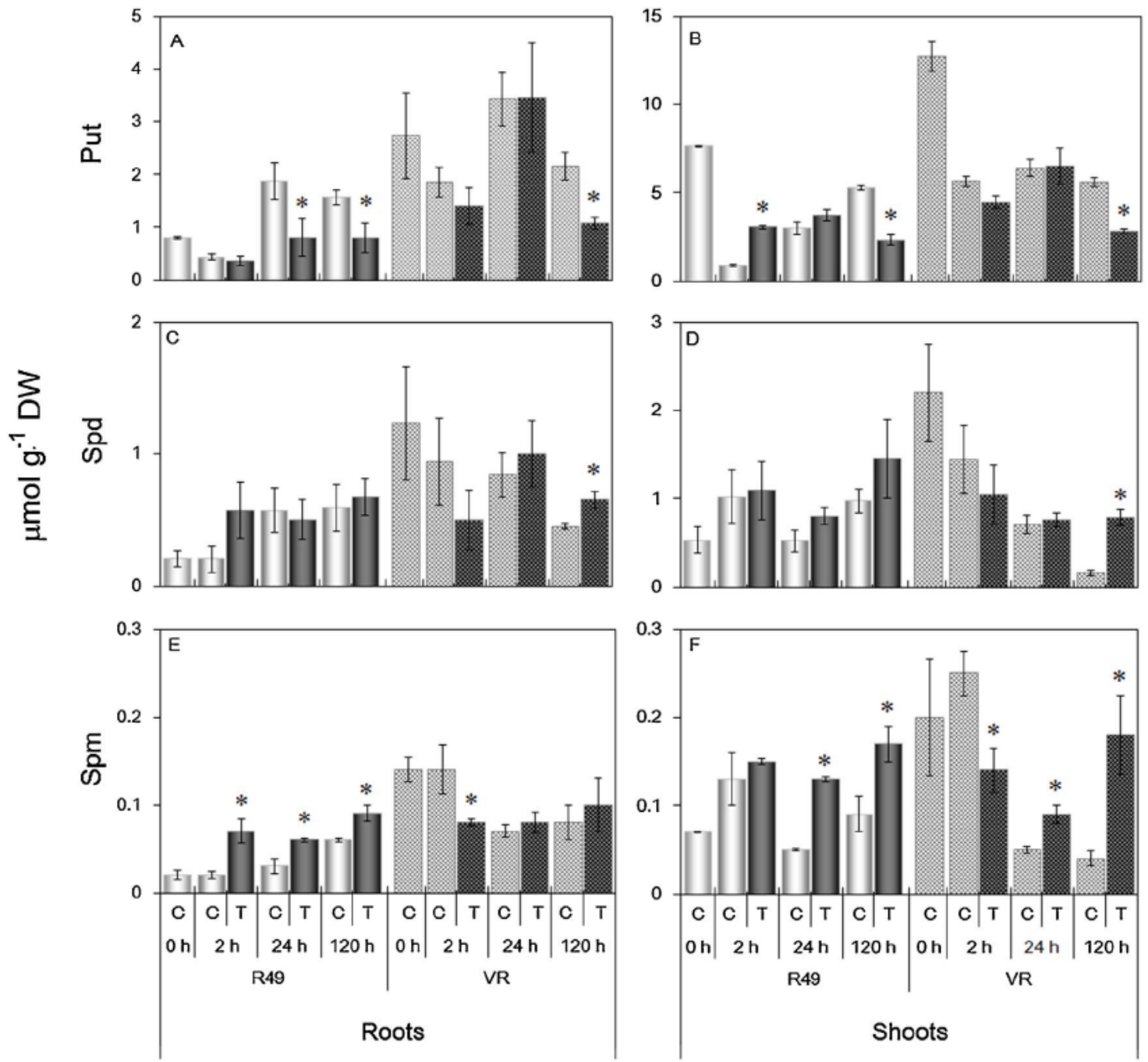

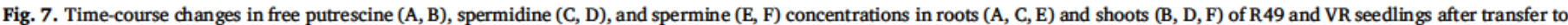
control $(C)$ and saline $(T)$ medium. Bars represent the $S E ; n=6$.

under salt treatment and in R49 more than in VR. Steeper root growth angles may be an alternative way to develop a deeper root system for soil exploration and as an avoidance mechanism (Lynch and Brown, 2012).

The presently observed salt induced growth reduction is in accord with the pattern of $C y c D 3$ expression, which was down regulated very early in roots and later in shoots after transfer to saline medium, likely due to the fact that the root is the first organ sensing soil salinity. It is well known that stressful conditions inhibit root growth and that cell cycle regulation is involved in this response; in fact, the expression of many cyclins is down regulated by salt/osmotic stress (Burssens et al., 2000; Zhao et al., 2014).

At the end of the experiment, the salt enhanced expression of the $\beta$ EXP1 gene in R49 roots, and its concomitant decline in shoots is coherent with salt induced shoot growth inhibition, but not with impaired root growth. This late increase in transcript levels may reflect an adaptive response. In fact, the up regulation of $\beta E X P 1$ coincided with the recovery of $C y c D 3$ transcript abundance to control levels. These changes may prepare R49 roots to adapt and, in the long term, to grow in an adverse environment consistent with the fact that root length increased from 5 to 12 DAT on saline medium. $\beta$ EXP1 transcript levels were also up regulated by salt in VR roots albeit earlier and to a lower extent than in R49, in accord with a slower long term root growth on saline medium in this landrace. Salt and osmotic stress have been shown to enhance expansin gene expression associated with growth reduction, which would appear to be in contrast with the role of expansins (Han et al., 2012; Zhao et al., 2012). In their transcriptomic profiling of salt stress induced genes in the halophyte Halogeton glomeratus, Wang et al., 2015 reported a number of unigenes that were identified as cell wall proteins. These wall loosening proteins may be involved in cell adaptation to salt, but their role is still poorly under stood.

In shoots of both landraces, the more pronounced down regulation of $\beta$ EXP1 and $C y c D 3$ as compared with roots was probably associated with a slowing down of both cell division and cell elongation responsible for reduced growth of the aerial organs, which, different from roots, continued up to 12 DAT.

\subsection{Genes involved in ion transport and homeostasis}

In order to exclude the potentially toxic $\mathrm{Na}^{+}$and $\mathrm{Cl}^{-}$ions away from important metabolic pathways, halophytes sequester substantial amounts of these ions in vacuoles (Lv et al., 2012) and, at the same time, maintain high cytoplasmic $\mathrm{K}^{+}$concentrations (Hanin et al., 2016), both major factors conferring 'tissue tolerance' under salinity stress (Munns et al., 2016).

$\mathrm{NHX}$ genes encode cation $/ \mathrm{H}^{+}$antiporters mediating compartmenta tion of $\mathrm{Na}^{+}$and $\mathrm{K}^{+}$ions into the vacuole (Hanin et al., 2016). In the halophytic species Suaeda salsa, SsNHX1 expression in leaves was up regulated by $500 \mathrm{mM} \mathrm{NaCl}$, suggesting that this $\mathrm{Na}^{+} / \mathrm{H}^{+}$antiporter 

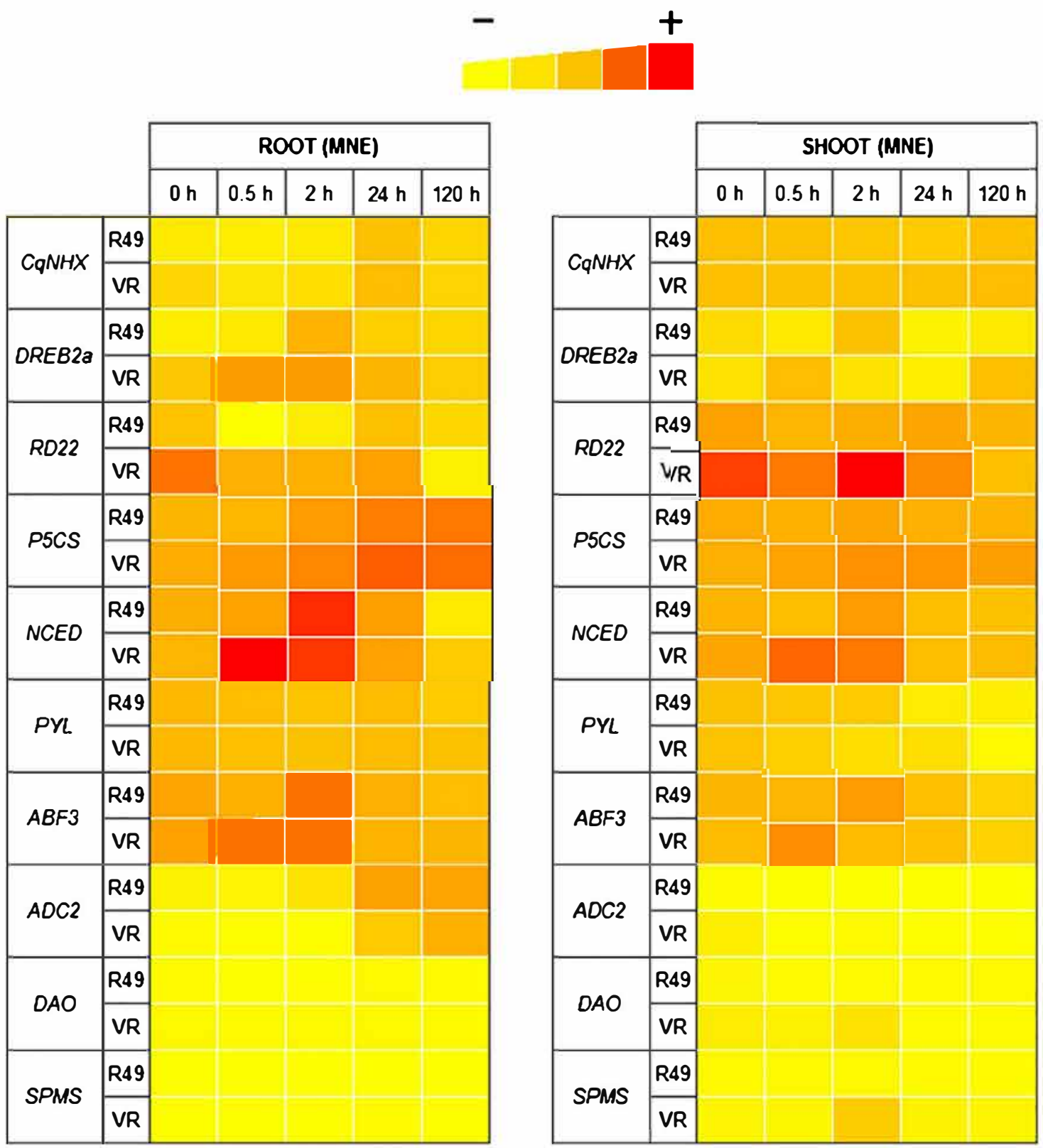

Fig. 8. Heatmap representation of the expression profiles (Mean Nannalized Expression, MNE) of ten selected genes at different times after transfer to soline medium. Darker and lighter colour shad ings represent relatively higher and lower expression levels, respectively. MNE values in shoots and roots were canpared separately.

plays a role in conferring the ability to cope with high salinity (Ma et al., 2004). Moreover, transgenic plants transformed with SsNHX1 (Zhao et al., 2006) or with SbNHX1 from Salicomia brachiata (Jha et al., 2013) accumulated less leaf cytosolic $\mathrm{Na}^{+}$and maintained higher $\mathrm{K}^{+} / \mathrm{Na}^{+}$ ratios than the wild type under $\mathrm{NaCl}$ treatment. In quinoa, we previously reported that CqNHX transcript abundance was differentially induced by $300 \mathrm{mM} \mathrm{NaCl}$ in shoots and roots and between quinoa genotypes; up regulation was observed in all landraces, except in the one that was, based on site of origin and other parameters, regarded as the most salt sensitive one (Ruiz Carrasco et al., 2011; Ruiz et al., 2016a). In the present work, the rapid and stronger CqNHX up regulation by salt in roots than in shoots of both landraces was possibly due to the fact that less salt was accumulated in the aerial parts as it had to be translocated from the roots. If the salt induced response of this gene is part of a general adaptive approach for reducing the damaging effect of ion accumulation, its similar expression pattern in the presently examined landraces does not reveal a different degree of tolerance based on this mechanism.
In Arabidopsis, AtHKT1;1 has been shown to function as $\mathrm{Na}^{+} / \mathrm{K}^{+}$ symporter and as $\mathrm{Na}^{+}$selective uniporter (Apse and Blumwald, 2007); it reduces leaf $\mathrm{Na}^{+}$accumulation by regulating retrieval of this ion from the xylem, while modulating $\mathrm{K}^{+}$nutrient status (Rus et al., 2004; Katschnig et al., 2015 and refs therein). In the halophyte Salicomia, high levels of shoot $\mathrm{Na}^{+}$concentration are achieved by complete suppression of $H K T$ combined with high SOS1 expression (Katschnig et al, 2015). Thus, the very low gene expression level of $H K T$ in quinoa seedlings as compared with the other two ion transporters may be a common mechanism associated with salt accumulation capacity in halophytes. In $S$. salsa, SsHKT1 also appears to be important for $\mathrm{K}^{+}$ uptake, especially under high salinity (Shao et al., 2008). The early, albeit transient, up regulation of HKT transcript levels in salt treated R49, as compared with the late and lower response in VR, may contribute to the capacity of the salares landrace in maintaining a proper $\mathrm{K}^{+}$status under high salinity.

SOS1 is a plasma membrane $\mathrm{Na}^{+} / \mathrm{H}^{+}$antiporter that mediates $\mathrm{Na}{ }^{+}$flux out of the cytoplasm and into the apoplast (Apse and Blumwald, 
2007). SOS1 seems involved in $\mathrm{Na}^{+}$xylem loading (Apse and Blumwald, 2007; Shabala et al., 2013) and, therefore, in long distance transport from roots to shoots (Shi et al., 2002). Halophytic chenopods are able to accumulate large amounts of $\mathrm{Na}^{+}$presumably via SOS1 mediated $\mathrm{Na}^{+}$ xylem loading (Shabala et al., 2013). Indeed, in Salicornia SOS1 gene expression was constitutively high (Katsching et al., 2015) and enhanced in response to $\mathrm{NaCl}$ (Yadav et al., 2012). Functional SOS1 analogues have been reported to be up regulated in quinoa following saline treatment (Maughan et al., 2009; Ruiz Carrasco et al., 2011) in accord with high leaf $\mathrm{Na}^{+}$concentrations (Hariadi et al., 2011; Orsini et al., 2011). Present results show that basal expression ( $0 \mathrm{~h})$ of CqSOS1 was comparable in R49 and VR, suggesting a similar potential for $\mathrm{Na}^{+}$ compartmentation in the vacuole and xylem loading. The gene was, however, up regulated by salt only in VR and in both organs, suggesting that this mechanism is more active in the coastal lowlands ecotype. As in Salicornia, SOS1 up regulation in VR root tissues may contribute to root to shoot $\mathrm{Na}^{+}$translocation, while expression in aerial parts may be associated with $\mathrm{Na}^{+}$efflux into the apoplast, thereby reducing cytoplasmic levels of the ion (Yadav et al., 2012).

\subsection{Genes related to signalling and downstream genes}

The DREB proteins are important APETALA2/Ethylene Responsive Factor transcription factors that regulate abiotic stress related genes. In Arabidopsis, DREB2 genes are induced by dehydration, salinity, and heat stresses (Lata and Prasad, 2011; Shavrukov et al., 2016); in particular, DREB2A and DREB2B are involved in osmotic stress responses through ABA independent pathways (Sakuma et al., 2002). In S. salsa, SsDREBa and $S s D R E B b$ were shown to respond to drought and high salt stress (Sun et al., 2015). Present results show that DREB2a was one of those genes that showed the strongest up regulation in response to salinity. The very early salt induced response of this gene, combined with a higher basal expression level in VR as compared with R49 indicates that the former is capable of a rapid adaptive response to salt stress.

The bZIP transcription factors are involved in developmental processes as well as in ABA mediated stress responses (Liu et al., 2014). In the woody halophyte Tamarix hispida, ThbZIP1 expression was related to increased drought and salt tolerance (Ji et al., 2013). In response to $\mathrm{NaCl}$ AtbZIP24 transcription was induced in the salt sensitive $A$. thaliana and repressed in its halophytic relative Lobularia maritima. The suppression of bZIP24 in L. maritima under salinity resulted in activated expression of genes involved in cytoplasmic ion homeostasis (e.g., AtHKT1; Yang et al., 2009). It is noteworthy that bZIP was the only gene encoding for a stress related transcription factor whose transcript levels in roots of both quinoa landraces were unaffected or decreased by salt throughout the experiment. This overall down regulation is in agreement with its proposed role as negative regulator of adaptation to salt stress (Popova et al., 2008) and correlates with the up regulation of HKT and CqSOS1.

Expression of the stress responsive $R D 22$ is increased by both exogenously applied and endogenous ABA produced under drought and salt stress (Shinozaki and Yamaguchi Shinozaki, 2007; Hanana et al., 2008). The Arabidopsis gene RD26 was shown to improve drought and/ or high salt stress tolerance when over expressed (Nakashima et al., 2014). The expression profile of RD22 differed in the two quinoa landraces. In VR, as compared to R49, this stress marker gene exhibited both a higher basal expression and a stronger and earlier salt induction, also in absolute terms. This suggests that $R D 22$ might be important at the earliest stages of salt stress in the coastal lowlands landrace in whose shoots it was the most highly expressed gene under saline conditions. On the other hand, in R49, $R D 22$ up regulation was maintained up to $120 \mathrm{~h}$ on saline medium, perhaps indicative of a role for this gene in the longer term adaptive response of the salares landrace.

\section{4. $A B A$ accumulation and $A B A$ related gene expression}

In many halophytic species, changes in levels of phytohormones and in the enzymes related to their biosynthesis have been reported in response to high salt concentration, with ABA exhibiting the strongest changes (Kumari et al., 2015). Present results confirm the salt induced increase in the expression of ABA biosynthesis and signaling genes, and in endogenous ABA concentrations in quinoa. Previously, changes in ABA levels in quinoa were determined in shoot and/or root xylem sap, and only under drought stress (Jacobsen et al., 2009; Razzaghi et al., 2011). Present results show that levels of $A B A$ and salt induced responses were very similar in the two landraces.

The up regulation of genes involved in the ABA pathway (i.e., NCED, $P Y R / P Y L, A B F 3)$ and accumulation of this hormone in shoots are consistent with the observed growth reduction in salt treated plants (Julkowska and Testerink, 2015). Although under salinity the growth reduction in R49 and VR roots was not associated with increased ABA content, enhanced expression of $\mathrm{ABA}$ related genes suggests that root system growth and architecture are also regulated in an ABA dependent manner. The differential accumulation of ABA in shoots and roots under salt stress is in agreement with the fact that dehydration induced ABA concentration is generally higher in aerial than belowground tissues (Jia et al., 2002 and references therein). Moreover, transport of ABA from roots to shoots may be enhanced during early adaptive responses to salt stress, when the biosynthetic pathway of this hormone is induced (Wilkinson and Davies, 2002). Finally, the ABA precursor pool is reportedly very large in shoots and able to satisfy the demand for stress induced ABA production needed for salt acclimation in this organ (e.g., stomatal closure, transpiration rate), whereas in roots the precursor pool is generally limited (Zhang et al., 2006).

Although the impact of salt stress on ABA accumulation in quinoa was different in individual organs, the expression patterns of the examined biosynthetic and signaling pathway genes were shared. Amongst all those analyzed, NCED was the gene exhibiting the highest absolute expression levels in roots and the strongest up regulation (salt treated $v s$ control) in both roots and shoots of salt treated quinoa seedlings, starting very early on, as previously reported for other species (Taji et al., 2004; Barrero et al., 2006; Geng et al., 2013; Zhang et al., 2006). As with ABA concentrations, the dynamics of NCED transcript accumulation were very similar in the two quinoa landraces in terms of timing, but the stronger up regulation in VR suggests a very efficient reaction to salt stress in this landrace. Nevertheless, the dramatic up regulation of NCED relative to other genes supports the notion that de novo biosynthesis plays a central role in enhancing $A B A$ levels in shoots of both quinoa landraces, in accord with the model proposed by Barrero et al., 2006. In roots, the up regulation of NCED under salinity may have been compensated by activation of the ABA catabolic pathway in order to maintain the homeostatic regulation of ABA levels and, therefore, ensure its growth regulatory and signaling function (Wilkinson and Davies, 2002). The observation that the $\beta$ glucosidase encoding gene $B G 1$ did not respond to salinity suggests that turnover of ABA GE to free $\mathrm{ABA}$ was not involved in the accumulation of free $\mathrm{ABA}$ in salt treated shoots, although we cannot completely rule this out as the levels of conjugated ABA were not determined. Similarly, a putative down regulation in glucosidase activity could not account for the lack of free ABA increase in roots. The fact that $B G 1$ expression was not up regulated by salt in quinoa also lends support to the notion that ABA GE is the long distance transport form of ABA playing a role in root to shoot stress signalling (Sauter et al., 2002).

In Arabidopsis, many of the ABA repressed genes encode ABA receptors (Finkelstein, 2013; Geng et al., 2013). In both R49 and VR, decreased $P Y R / P Y L$ transcript levels under salinity relative to controls accompanied by enhanced hormone biosynthetic capacity and content confirm this negative feedback loop during ABA mediated signaling. Increased hormone production compensated by reduced perception regulates downstream $\mathrm{ABA}$ induced responses, some of which can be 
deleterious (Lee et al., 2015).

$\mathrm{ABFs}$ are amongst those transcription factors regulating gene expression in response to abiotic stresses in an ABA dependent manner. The involvement of $\mathrm{ABFs}$ in stress tolerance has been revealed via engineering transgenic Arabidopsis lines constitutively over expressing $A B F 3$ and $A B F 4$ (Kang et al., 2002). In quinoa, $A B F 3$ was, together with $N C E D$, an "early response gene" in the ABA signalling pathway under salinity. ABA triggers signaling cascades controlling the expression of many downstream genes whose products may confer tolerance, such as membrane localized ion transporters (Osakabe et al., 2014). Here we show that CqSOS1 and, especially, CqNHX and $H K T$ were all up regulated by salt, pointing to a positive correlation with up regulation of the ABA pathway.

\subsection{Polyamines and expression of genes involved in PA and proline metabolism}

Present results show that salt stress induced a PA response, both in terms of content and biosynthetic/oxidative gene expression, starting from $2 \mathrm{~h}$ after transfer. The observed reduction in Put levels has been reported in other species exposed to salinity stress; the inverse relation ship with tissue levels of $\mathrm{Na}^{+}$or $\mathrm{K}^{+}$may be related to the purported role of this diamine in maintaining the cation/anion balance (Liu et al., 2008). On the contrary, tissue concentrations of Spd and, especially, $\mathrm{Spm}$ tended to increase. The protective role of the higher PAs in plants exposed to abiotic stresses is well established (Groppa and Benavides, 2008; Wen et al., 2008). Thus, over expression of SAMDC, SPDS, and SPMS genes has been shown to enhance stress tolerance (Marco et al., 2011) and a Put to Spm metabolic flux in response to drought has been described (Alcázar et al., 2011).

The presently observed changes in PA contents led to a salt induced increase in the (Spd $+\mathrm{Spm}$ )/Put ratio, a feature that has been positively associated with stress tolerance (Duan et al., 2008). In roots and shoots of $\mathrm{R} 49$, the ratio was enhanced by $\mathrm{NaCl}$ treatment at all time points, while in VR, it increased only at $120 \mathrm{~h}$ after transfer to saline medium. Although the response occured later, the ratio in VR was significantly higher than in R49. Previously, we showed that the extent to which the ratio between the higher PAs and the diamine changed under salinity may allow to distinguish between quinoa genotypes originating from different habitats (Ruiz Carrasco et al., 2011).

In seedlings of both R49 and VR basal expression of $A D C 1$ was the highest of all those analyzed, followed by SPDS, pointing to the importance of PAs for seedling growth (Minocha et al., 2014). This high $A D C 1$ expression at $0 \mathrm{~h}$ correlated positively with the relatively high concentration of Put. Transfer to saline medium did not signifi cantly affect, or even down regulated, transcript levels of $A D C 1$, as also observed for other PA biosynthetic genes (ODC, $S A M D C)$. By contrast, $A D C 2$ exhibited an early (shoots) and late (roots) up regulation in response to salt In fact, evidence suggests that $A D C 1$ and $A D C 2$ are differentially affected by salinity, with $A D C 1$ being reduced relative to controls and $A D C 2$ strongly up regulated in tolerant rice cultivars (Do et al., 2014). In Arabidopsis, inducibility of $A D C 2$ by osmotic stress and its importance in conferring drought tolerance have likewise been described (Alcázar et al., 2010). ADC2 over expression leads, in turn, to up and down regulation of several stress, hormone, and signaling related genes (Pál et al., 2015). In the halophyte Sporobolus virzinicus, Yamamoto et al., 2015 reported that PA biosynthetic genes, namely $A D C$ and SPDS, were salinity induced. Different from VR, SPDS1 gene expression in R49 was not affected by salt and Spd levels were scarcely affected. On the other hand, in both landraces, the higher expression of SPMS relative to controls was in accord with Spm accumulation occurring late after transfer, but could not account for the early increase in Spm levels. Up regulation of PA biosynthetic genes under drought stress have been shown to be an ABA dependent response (Alcázar et al., 2010). Consequently, $P A s$ and $A B A$ are integrated in a positive feedback loop in response to abiotic stress (Pál et al., 2015). Thus, the
PA response observed in R49 and VR could be a consequence of the early up regulation of NCED, which preceded that of the PA biosyn thetic genes and the increase in ABA levels.

DAOs and PAOs also play a role in stress tolerance both by regulating free PAs levels and by generating molecules (hydrogen peroxide and $\gamma$ aminobutyric acid) involved in signaling and stress protection (Cona et al., 2006; Pottosin and Shabala, 2014). In the present study, DAO up regulation in response to salt would confirm its positive role in reducing Put content and in producing stress protective molecules.

In addition to their osmoprotective role, organic osmolytes such as proline play a role in contrasting oxidative stress under $\mathrm{NaCl}$ treatment (Szabados and Savouré, 2010). The proline biosynthetic genes such as P5CS are induced by salt stress (Song and Wang, 2015) and this up regulation is ABA dependent (Strizhov et al., 1997). The presently observed overall up regulation of P5CS transcript levels in the presence of $\mathrm{NaCl}$ is coherent with salt enhanced proline concentrations previously reported for Chilean landraces of quinoa (Orsini et al., 2011; Ruiz Carrasco et al., 2011).

\subsection{Timing of salt induced events}

The importance of timescale in plant responses to salinity has been pointed out At the short term (i.e., up to 5 days), similarities between the two quinoa landraces from contrasting environments point to a comparable salt adaptation mechanism during which, according to Munns, 2002, responses are essentially similar to those induced by drought. Based on the most salient changes in gene expression (Fig. 9) and on variations in $\mathrm{ABA}$ and PA contents that were common to both landraces, the response of quinoa seedlings over time followed a sequence of events (Table 2). Within minutes $(0.5 \mathrm{~h})$, the immediate activation of the $A B A$ dependent pathway preceded $A B A$ accumulation. Over hours ( $2 \mathrm{~h}$ ), an ABA independent signalling pathway (DREB2A) was also induced together with genes linked to proline and PA metabolism. During this early phase, the down regulation of $\mathrm{CycD} 3$ in roots supports the rapid need to reprogramme growth in this organ. All these early events are normally triggered by primary osmotic stresses. Within days, the continued up regulation of ABA dependent and

-independent genes as well as accumulation of ABA was observed. The up regulation of PA genes led to a typical salt stress responsive PA profile. The overall ABA response might also be implicated in the activation of stress marker genes, such as RD22. Ion homeostasis is a slower response (Munns, 2002) as shown by the fact that up regulation of genes (e.g., CqNHX) in most cases occurred from $24 \mathrm{~h}$ onwards. In accord with the later reduction in shoot growth as compared with roots under osmotic stress (Chaves et al., 2003), the down regulation of CycD3 appeared in shoots at this stage. At the latest time point $(120 \mathrm{~h})$, the induction of expansins may reveal a preparatory growth response for long term acclimation by cell wall adjustment.

\section{Conclusions}

Being a facultative halophyte, quinoa is intrinsically well adapted to saline soil. Here we show that, at the short term, landraces from contrasting habitats, R49 and VR, responded to high salinity under in vitro conditions in essentially a similar manner. In fact, none of the genes can be regarded as displaying a highly specific salt induced response in one landrace versus the other. The common responses were more numerous in roots than in shoots. The strongest similarity was in the activation of the ABA pathway, especially in shoots, probably due to the importance of rapidly regulating plant water status.

In spite of these similarities, the timing of the onset of altered gene expression, in some cases, reflected genotype dependent constitutive, and inducible adaptive strategies. In R49, the latter include the very early up regulation of ion homeostasis genes, suggesting that this landrace is better equipped to control salt uptake, translocation, and 


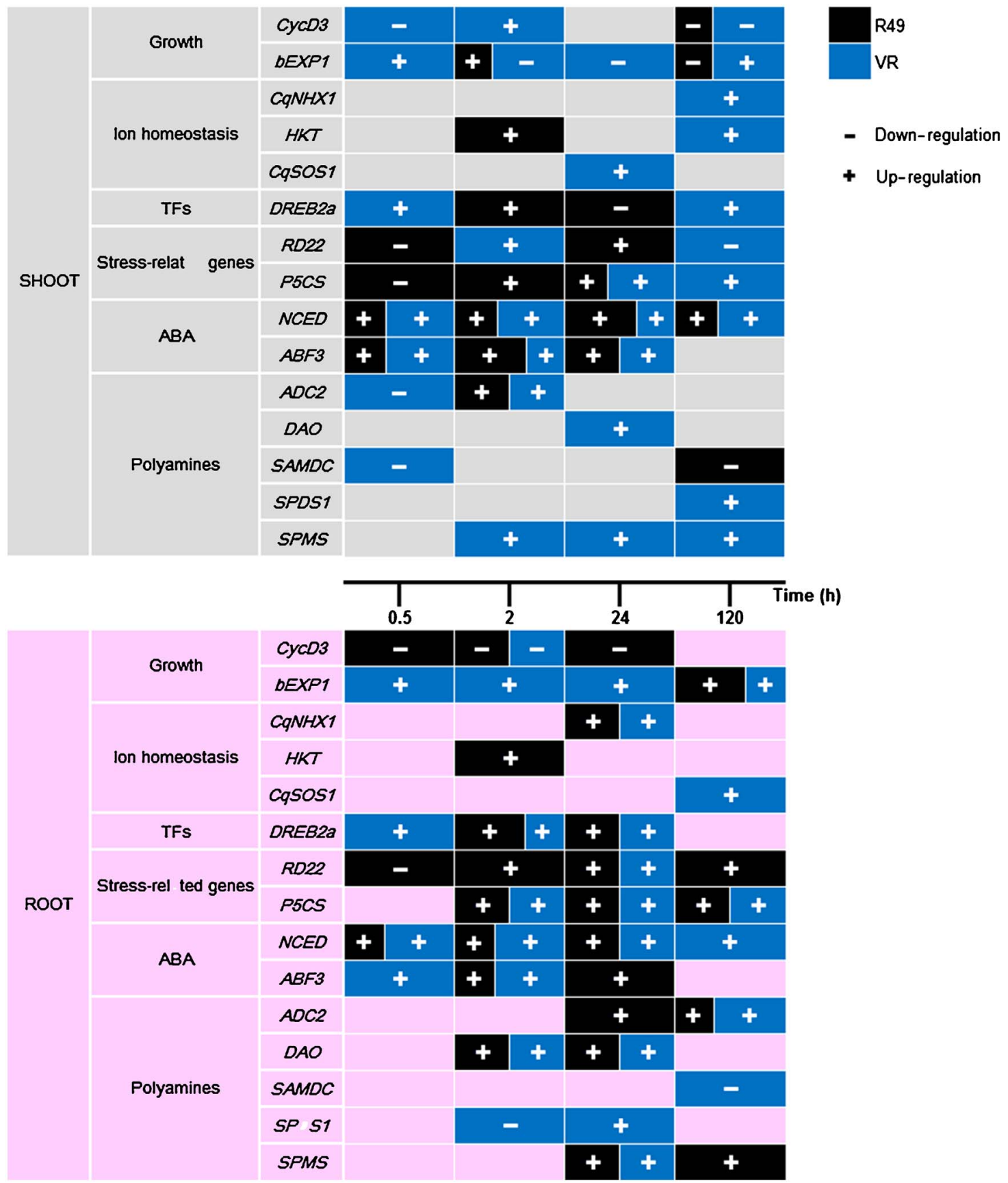

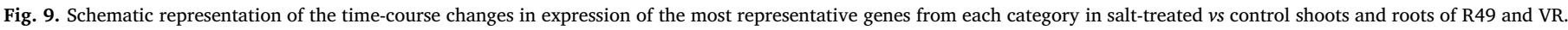
The size of the boxes reflects the relative up- or down-regulation of one landrace compared with the other. TFs, transcription factors.

Table 2

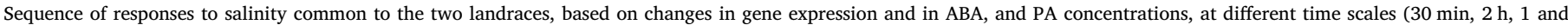
5 days). *, response only at 5 days.

\begin{tabular}{|c|c|c|}
\hline Time & Roots & Shoots \\
\hline Minutes & Induction of $\mathrm{ABA}$ biosynthesis (NCED) & Induction of $\mathrm{ABA}$ pathway (NCED, ABF3) \\
\hline Hours & $\begin{array}{l}\text { Growth inhibition ( } C y c D 3) \text {, activation of ABA pathway (NCED, ABF), ABA- } \\
\text { independent transcription factor (DREB2a), proline biosynthesis (P5CS), and Put } \\
\text { oxidation (DAO) }\end{array}$ & $\begin{array}{l}\text { Activation of ABA pathway ( } N C E D, A B F) \text {, and PA biosynthesis ( } A D C 2) \text {. Increased } \\
\text { ABA levels }\end{array}$ \\
\hline Days & $\begin{array}{l}\text { Induction of } \beta \text {-EXP1*; up-regulation of ion transporter (CqNHX); continued up- } \\
\text { regulation of ABA biosynthesis (NCED), ABA-independent transcription factor } \\
(D R E B 2 a) \text {, proline biosynthesis (P5CS), Put biosynthesis (ADC2)* and Put } \\
\text { oxidation (DAO). Induction of stress-related gene (RD22) and Spm biosynthesis } \\
(S P M S) \text {; reduced Put content. } \\
\text { align = "center" }\end{array}$ & $\begin{array}{l}\text { Growth inhibition }(C y c D 3)^{*} \text {; continued up-regulation of ABA pathway (NCED, } \\
A B F 3) \text {, and activation of proline biosynthesis }(P 5 C S) \text {; increased ABA levels; } \\
\text { reduced Put and increased Spm contents. }\end{array}$ \\
\hline
\end{tabular}


compartmentalization compared to VR. Modulation of the PA profile was also among the earliest responses of R49 to high salinity, an important protective mechanism that was maintained up to the end of the experiment. On the other hand, VR showed an interesting predis position for salinity tolerance by highly expressing NCED, RD22, and DREB2 $a$ and by having a high content of stress protective molecules (ABA, and PAs) already at the time of transfer. After transfer to saline medium, VR exhibited, as compared with R49, earlier and/or stronger changes in transcript levels of growth related genes and of those related to ABA (NCED, ABF3, and RD22), indicating that controlling plant water status could be a major requirement in this landrace. Moreover, in response to salt, VR was characterized by up regulation of transcripts involved in proline and PA metabolism at the shoot, and not only root, level. Finally, in VR, the higher expression of proline and PA related genes up to a late stage of salt exposure and the late response in terms of PA ratio may be justified by the need for long term protection from ion toxicity. The ability of this coastal lowlands landrace to respond positively to salinity may derive from the fact that, despite its inland habitat, it is potentially exposed to sea salt aerosols, which after long range atmospheric transport from coastal regions (Lee et al., 2014), might reach these plants.

Establishing criteria for describing the stress tolerance level of quinoa genotypes has proven a difficult task. In the near future, more extensive transcriptomic data will further contribute to addressing this issue and provide information on the basic mechanisms of short term and long term salt stress tolerance in quinoa, a model halophyte crop that can provide new insight into the mechanisms of salt tolerance in plants (Ruiz et al., 2016b). In view of the global expansion of quinoa cultivation (Bazile et al., 2016), this molecular approach will also provide support, e.g., via marker assisted selection (Hanin et al., 2016), in breeding for improved varieties adapted to soil and climatic conditions in new regions around the world.

\section{Authors' contributions}

KBR designed the experiments, produced the plant material, performed the QRT PCR analyses, analyzed the data, and prepared the figures; FR performed the biochemical and statistical analyses; GB contributed to the ABA analyses; SB, HS and PT supervised the research and interpreted the data; SB and FR wrote the article with contributions from all other authors.

\section{Acknowledgements}

This research was supported by funds from CONICYT (Chile) and the University of Bologna (RFO 2015). FONDECYT (Chile) No. 3130624 and University of Bologna No. REP33/2015 and REP54/2016 post doctoral grants to KBR are gratefully acknowledged. The authors thank Dr. Pedro León (Seed Bank, INIA Vicuña, Chile) for supplying the seeds and Michelangelo Gambelli for support in the growth experiments. We also thank Dr. Jonathan Maldonado (University of Chile) for making available the quinoa RNAseq database.

\section{References}

Abràmoff, M.D., Magalhães, P.J., Ram, S.J., 2004. Image processing with Image. J. Biophoton. Int. 11, 36-42.

Adolf, V.I., Shabala, S., Andersen, M.N., Razzaghi, F., Jacobsen, S.-E., 2012. Varietal differences of quinoa's tolerance to saline conditions. Plant Soil 357, 117-129. http://dx.doi.org/10.1007/s11104-012-1133-7.

Adolf, V.I., Jacobsen, S.-E., Shabala, S., 2013. Salt tolerance mechanisms in quino (Chenopodium quinoa Willd.). Environ. Exp. Bot. 92, 43-54. http://dx.doi.org/10. 1016/j.envexpbot.2012.07.004.

Albaladejo, I., Meco, V., Plasencia, F., Flores, F.B., Bolarin, M.C., Egeam, I., 2017. Unravelling the strategies used by the wild tomato species Solanum pennellii to confront salt stress: from leaf anatomical adaptations to molecular responses. Environ. Exp. Bot. 135, 1-12. http://dx.doi.org/10.1016/j.envexpbot.2016.12.003.

Alcázar, R., Tiburcio, A.F., 2014. Plant polyamines in stress and development: an emerging area of research in plant sciences. Front. Plant Sci. 5, 319. http://dx.doi. org $/ 10.3389 /$ fpls.2014.00319.

Alcázar, R., Planas, J., Saxena, T., Zarza, X., Bortolotti, C., Cuevas, J., Bitrián, M., Tiburcio, A.F., Altabella, T., 2010. Putrescine accumulation confers drought tolerance in transgenic Arabidopsis plants over-expressing the homologous arginine decarboxylase2 gene. Plant Physiol. Biochem. 48, 547-552. http://dx.doi.org/10. 1016/j.plaphy.2010.02.002.

Alcázar, R., Bitrián, M., Bartels, D., Koncz, C., Altabella, T., Tỉburcio, A.F., 2011. Polyamine metabolic canalization in response to drought stress in Arabidopsis and the resurrection plant Craterostigma plantagineum. Plant Signal. Behav. 6, 243-250. http://dx.doi.org/10.4161/psb.6.2.14317.

Apse, M.P., Blumwald, E., 2007. $\mathrm{Na}^{+}$transport in plants. FEBS Lett. 581, 2247-2254. http://dx.doi.org/10.1016/j.febslet.2007.04.014.

Barrero, J., Rodríguez, P.L., Quesada, V., Piqueras, P., Ponce, M.R., Micol, J.L., 2006. Both abscisic acid (ABA)-dependent and ABA-independent pathways govem the induction of NCED3AAO3 and ABA1 in response to salt stress. Plant Cell Environ. 29, 2000-2008. http://dx. doi.org/10.1111/j.1365-3040.2006.01576.x.

Bazile, D., Jacobsen, S.E., Verniau, A., 2016. The global expansion of quinoa: trends and limits. Front. Plant Sci. 7, 6-22. http://dx.doi.org/10.3389/fpls.2016.00622. Bendevis, M.A., Sun, Y., Shabala, S., Rosenqvist, E., Liu, F., Jacobsen, S.E., 2014. Differentiation of photoperiod-induced ABA and soluble sugar responses of two quinoa (Chenopodium quinoa Willd.) cultivars. J. Plant Growth Regul. 33, 562-570. http://dx.doi.org/10.1007/s00344-013-9406-9.

Bonales-Alatorre, E., Shabala, S., Chen, Z.H., Pottosin, I., 2013. Reduced tonoplast fastactivating and slow-activating channel activity is essential for conferring salinity tolerance in a facultative halophyte, quinoa. Plant Physiol. 162, 940-952. http://dx. doi.org/10.1016/S0021-9673(01)96061-3.

Burssens, S., Himanen, K., van de Cotte, B., Beeckman, T., Van Montagu, M., Inzé, D., Verbruggen, N., 2000. Expression of cell cycle regulatory genes and morphological alterations in response to salt stress in Arabidopsis thaliana. Planta 211, 632-640. http://dx.doi.org/10.1007/s004250000334.

Chang, S., Puryear, J., Cairney, J., 1993. A simple and efficient method for isolating RNA from pine trees. Plant Mol. Biol. Rep. 11, 113-116. http://dx.doi.org/10.1007/ BF02670468.

Chaves, M.M., Maroco, J.P., Pereira, J.S., 2003. Understanding plant responses to drought-from genes to the whole plant. Funct. Plant Biol. 30, 239-264.

Cohen, J.D., Baldi, B.G., Slovin, J.P., 1986. C (6)-[benzene ring]-indole-3-acetic acid: a new internal standard for quantitative mass spectral analysis of indole-3-acetic acid in plants. Plant Physiol. 80, 14-19. http://dx.doi.org/10.1104/pp.80.1.14.

Cohen, J.D., 1984. Convenient apparatus for the generation of small amounts of diazomethane. J. Chromatogr. A 303, 193-196. http://dx.doi.org/10.1016/ S0021-9673(01)96061-3.

Cona, A., Rea, G., Angelini, R., Federico, R., Tavladoraki, P., 2006. Functions of amine oxidases in plant development and defence. Trends Plant Sci. 11, 80-88. http://dx. doi.org/10.1016/j.tplants.2005.12.009.

Do, P.T., Drechsel, O., Heyer, A.G., Hincha, D.K., Zuther, E., 2014. Changes in free polyamine levels, expression of polyamine biosynthesis genes, and performance of rice cultivars under salt stress: a comparison with responses to drought. Front. Plant Sci. 5, 182. http://dx.doi.org/10.3389/fpls. 2014.00182.

Dong, T., Park, Y., Hwan, I., 2015. Abscisic acid: biosynthesis, inactivation, homoeostasis and signalling. Essays Biochem. 58, 29-48. http://dx.doi.org/10.1042/BSE0580029. Duan, J.J., Li, J., Guo, S.R., Kang, Y.Y., 2008. Exogenous spermidine affects polyamine metabolism in salinity-stressed Cucumis sativus roots and enhances short-term salinity tolerance. J. Plant Physiol. 165, 1620-1635. http://dx.doi.org/10.1016/j.jplph.2007. 11.006.

Finkelstein, R., 2013. Abscisic acid synthesis and response. Arabidopsis Book 11, e0166. http://dx.doi.org/10.1199/tab.0166.

Fuentes, F.F., Martínez, E.A., Hinrichsen, P.V., Jellen, E.N., Maughan, P.J., 2009. Assessment of genetic diversity patterns in Chilean quinoa (Chenopodium quinoa Willd.) germplasm using multiplex fluorescent microsatellite markers. Conserv. Genetics 10, 369-377. http://dx doi.org/10.1007/s10592-008-9604-3.

Gómez-Pando, L.R., Álvarez-Castro, R., Eguiluz-de la Barra, A., 2010. Short communication: effect of salt stress on Peruvian germplasm of Chenopodium quinoa Willd.: a promising crop. J. Agric. Crop Sci. 196, 391-396. http://dx.doi.org/10. 1111/j.1439-037X.2010.00429.x.

Geng, Y., Wu, R., Wee, C.W., Xie, F., Wei, X., Chan, P.M.Y., Tham, C., Duan, L., Dinneny, J.R., 2013. A spatio-temporal understanding of growth regulation during the salt stress response in Arabidopsis. Plant Cell 25, 2132-2154. http://dx.doi.org/10.1105/ tpc.113.112896.

Ghuge, S.A., Carucci, A., Rodrigues-Pousada, R.A., Tisi, A., Franchi, S., Tavladoraki, P., Angelini, R., Cona, A., 2015. The MeJA-inducible copper amine oxidase AtAO1 is expressed in xylem tissue and guard cells. Plant Signal. Behav. 10 (10), e1073872 http://dx.doi.org/10.1080/15592324.2015.1073872.

Golldack, D., Li, C., Mohan, H., Probst, N., 2014. Tolerance to drought and salt stress in plants: unraveling the signaling networks. Front. Plant Sci. 5, 151. http://dx.doi.org/ 10.3389/fpls.2014.00151.

Groppa, M.D., Benavides, M.P., 2008. Polyamines and abiotic stress: recent advances. Amino Acids 34, 35. http://dx.doi.org/10.1007/s00726-007-0501-8.

Han, Y.Y., Li, A.X., Li, F., Zhao, M.R., Wang, W., 2012. Characterization of a wheat (Triticum aestivum $\mathrm{L}_{\text {) }}$ expansin gene, TaEXPB23, involved in the abiotic stress response and phytohormone regulation. Plant Physiol. Biochem. 54, 49-58. http://dx.doi.org/10.1016/j.plaphy, 2012.02.007.

Hanana, M., Deluc, L., Fouquet, R., Daldoul, S., Leon, C., Barrieu, F., Ghorbel, A., Mliki, A., Hamdi, S., 2008. Identification and characterization of ' $r d 22$ ' dehydration responsive gene in grapevine (Vitis vinifera L.). Mol. Biol. Genet. 331, 569-578. http://dx.doi.org/10.1016/j.crvi.2008.05.002.

Hanin, M., Ebel, C., Ngom, M., Laplaze, L., Masmoudi, K., 2016. New insights on plant salt 
tolerance mechanisms and their potential use for breeding. Front. Plant Sci. 7, 1787.

http://dx.doi.org/10.3389/fpls.2016.01787

Hariadi, Y., Marandon, K., Tian, Y., Jacobsen, S.E., Shabala, S., 2011. Ionic and osmotic relations in quinoa (Chenopodium quinoa Willd.) plants grown at various salinity levels. J. Exp. Bot. 62, 185-193. http://dx.doi.org/10.1093/jxb/erq257.

Ismail, A., Takeda, S., Nick, P., 2014. Life and death under salt stress: same players, different timing? J. Exp. Bot. 65, 2963-2979. http://dx.doi.org/10.1093/jxb/eru159.

Jacobsen, S.E., Liu, F., Jensen, C.R., 2009. Does root-sourced ABA play a role for regulation of stomata under drought in quinoa (Chenopodium quinoa Willd.). Sci. Hortic. 122, 281-287. http://dx.doi.org/10.1016/j.scienta.2009.05.019.

Jha, B., Mishra, A., Jha, A., Joshi, M., 2013. Developing transgenic Jatropha using the SbNHX1 gene from an extreme halophyte for cultivation in saline wasteland. PLoS One 8, e71136. http://dx.doi.org/10.1371/journal.pone.0071136.

Ji, X., Liu, G., Liu, Y., Zheng, L., Nie, X., Wang, Y., 2013. The bZIP protein from Tamarix hispida, ThbZIP1, is ACGT elements binding factor that enhances abiotic stress signaling in transgenic Arabidopsis. BMC Plant Biol. 13, 151. http://dx.doi.org/10. 1186/1471-2229-13-151.

Jia, W., Wang, Y., Zhang, S., Zhang, J., 2002. Salt-stress-induced ABA accumulation is more sensitively triggered in roots than in shoots. J. Exp. Bot. 53, 2201-2206. http:// dx.doi.org/10.1093/jxb/erf079.

Julkowska, M.M., Testerink, C., 2015. Tuning plant signaling and growth to survive salt. Trends Plant Sci. 20, 586-594. http://dx.doi.org/10.1016/j.tplants.2015.06.008. Kang, J.Y., Choi, H.I., Im, M.Y., Kim, S.Y., 2002. Arabidopsis basic leucine zipper proteins that mediate stress-responsive abscisic acid signaling. Plant Cell 14, 343-357. http:// dx.doi.org/10.1105/tpc.010362.

Katschnig, D., Bliek, T., Rozema, J., Schat, H., 2015. Constitutive high-level SOS1 expression and absence of $H K T 1 ; 1$ expression in the salt-accumulating halophyte Salicornia dolichostachya. Plant Sci. 234, 144-154. http://dx.doi.org/10.1016/j . plantsci.2015.02.011.

Kumari, A., Das, P., Parida, A.K., Agarwal, P.K., 2015. Proteomics, metabolomics, and ionomics perspectives of salinity tolerance in halophytes. Front. Plant Sci. 6, 537.

http://dx.doi.org/10.3389/fpls.2015.00537.

Kusano, T., Berberich, T., Tateda, C., Takahashi, Y., 2008. Polyamines: essential factors for growth and survival. Planta 228, 367-381. http://dx.doi.org/10.1007/ s00425-008-0772-7.

Lata, C., Prasad, M., 2011. Role of DREBs in regulation of abiotic stress responses in plants. J. Exp. Bot. 62, 4731-4748. http://dx.doi.org/10.1093/jxb/err210.

Lee, K.H., Piao, H.L., Kim, H.Y., Choi, S.M., Jiang, F., Hartung, W., Hwang, I., Kwak, J.M., Lee, I.J., Hwang, I., 2006. Activation of glucosidase via stress-induced polymerization rapidly increases active pools of abscisic acid. Cell 126, 1109-1120. http://dx.doi. org/10.1016/j.cell.2006.07.034.

Lee, Y.N., Springston, S., Jayne, J., Wang, J., Hubbe, J., Senum, G., Kleinman, L., Daum, P.H., 2014. Chemical composition and sources of coastal marine aerosol particles during the 2008 VOCALS-REx campaign. Atmos. Chem. Phys. 14, 5057-5072. http://www.atmos-chem-phys.net/14/5057/2014.

Lee, H.-N., Lee, K.-H., Kim, C.S., 2015. Abscisic acid receptor PYRABACTIN RESISTANCELIKE $8 P Y L 8$, is involved in glucose response and dark-induced leaf senescence in Arabidopsis. Biochem. Biophys. Res. Commun. 463, 24-28. http://dx.doi.org/10. 1016/j.bbrc.2015.05.010.

Liu, J.H., Inoue, H., Moriguchi, T., 2008. Salt stress-mediated changes in free polyamine titers and expression of genes responsible for polyamine biosynthesis of apple in vitro shoots. Environ. Exp. Bot. 62, 28-35. http://dx. doi.org/10.1016/j.envexpbot.2007. 07.002 .

Liu, C., Mao, B., Ou, S., Wang, W., Liu, L., Wu, Y., Chu, C., Wang, X., 2014. OsbZIP71, a bZIP transcription factor, confers salinity and drought tolerance in rice. Plant Mol. Biol. 84, 19-36. http://dx.doi.org/10.1007/s11103-013-0115-3.

Lv, S., Jiang, P., Chen, X., Fan, P., Wang, X., Li, Y., 2012. Multiple compartmentalization of sodium conferred salt tolerance in Salicornia europaea. Plant Physiol. Biochem. 51, 47-52. http://dx.doi.org/10.1016/j.plaphy.2011.10.015.

Lynch, J.P., Brown, K.M., 2012. New roots for agriculture: exploiting the root phenome. Philos. Trans. R. Soc. Lond. B Biol. Sci. 367, 1598-1604. http://dx.doi.org/10.1098/ rstb.2011.0243.

Müller, M., Munné-Bosch, S., 2011. Rapid and sensitive hormonal profiling of complex plant samples by liquid chromatography coupled to electrospray ionization tandem mass spectrometry. Plant Methods 7, 37. http:// dx. doi.org/10.1186/1746-4811-7-37.

Ma, X.L., Zhang, Q., Shi, H.Z., Zhu, J.K., Zhao, Y.X., Ma, C.L., Zhang, H., 2004. Molecular cloning and different expression of a vacuolar $\mathrm{Na}+/ \mathrm{H}+$ antiporter gene in Suaeda salsa under salt stress. Biol. Plant. 48, 219-225. http://dx.doi.org/10.1023/B:BIOP 0000033448.96998 .44

Marco, F., Alcázar, R., Tiburcio, A.F., Carrasco, P., 2011. Interactions between polyamines and abiotic stress pathway responses unraveled by transcriptome analysis of polyamine overproducers. OMICS 15, 775-781. http://dx.doi.org/10.1089/omi. 2011.0084

Maughan, P.J., Turner, T.B., Coleman, C.E., Elzinga, D.B., Jellen, E.N., Morales, J.A., Udall, J.A., Fairbanks, D.J., Bonifacio, A., 2009. Characterization of Salt overly sensitive 1 (SOS1) gene homoeologs in quinoa (Chenopodium quinoa Willd.). Genome 52, 647-657. http://dx.doi.org/10.1139/G09-041.

Minocha, R., Majumdar, R., Minocha, S.C., 2014. Polyamines and abiotic stress in plants: a complex relationship. Front. Plant Sci. 5, 175. http://dx.doi.org/10.3389/fpls. 2014.00175.

Morales, A., Zurita-Silva, A., Maldonado, J., Silva, H., 2017. Transcriptional responses of Chilean quinoa (Chenopodium quinoa Willd.) under water deficit conditions uncovers ABA-independent expression patterns. Front. Plant Sci. 8, 216. http://dx.doi.org/10. 3389/fpls.2017.00216

Muller, P.Y., Janovjak, H., Miserez, A.R., Dobbie, Z., 2002. Short technical report processing of gene expression data generated by quantitative real-time RT-PCR. Biotechniques 32 (6), 1372-1379.

Munns, R., James, R.A., Gilliham, M., Flowers, T.J., Colmer, T.D., 2016. Tissue tolerance: an essential but elusive trait for salt-tolerant crops. Funct. Plant Biol. 43, 1103-1113. http://dx.doi.org/10.1071/FP16187.

Munns, R., 2002. Comparative physiology of salt and water stress. Plant Cell Environ. 25 239-250. http://dx.doi.org/10.1046/j.0016-8025.2001.00808.x.

Munns, R., 2005. Genes and salt tolerance: bringing them together. New Phytol. 167, 645-663. http://dx.doi.org/10.1111/j.1469-8137.2005.01487.x.

Murashige, T., Skoog, F., 1962. A revised medium for rapid growth and bio assays with tobacco tissue cultures. Physiol. Plant. 15, 473-497. http://dx.doi.org/10.1111/j. 399-3054.1962.tb08052.x

Nakashima, K., Yamaguchi-Shinozaki, K., Shinozaki, K., 2014. The transcriptional regulatory network in the drought response and its crosstalk in abiotic stress responses including drought, cold, and heat. Front. Plant Sci. 5, 170. http://dx.doi. org $/ 10.3389 / \mathrm{fpls} .2014 .00170$.

Orsini, F., Accorsi, M., Gianquinto, G., Dinelli, G., Antognoni, F., Ruiz-Carrasco, K.B., Martinez, E.A., Alnayef, M., Marotti, I., Bosi, S., Biondi, S., 2011. Beyond the ionic and osmotic response to salinity in Chenopodium quinoa: functional elements of successful halophytism. Funct. Plant Biol. 38, 818-831. http://dx.doi.org/10.1071/ FP11088.

Osakabe, Y., Yamaguchi-Shinozaki, K., Shinozaki, K., Tran, L.S.P., 2014. ABA control of plant macroelement membrane transport systems in response to water deficit and high salinity. New Phytol. 202, 35-49. http://dx. doi.org/10.1111/nph.12613.

Pál, M., Szalai, G., Janda, T., 2015. Speculation: polyamines are important in abiotic stress signaling. Plant Sci. 237, 16-23. http://dx.doi.org/10.1016/j.plantsci.2015.05. 003.

Popova, O.V., Yang, O., Dietz, K.J., Golldack, D., 2008. Differential transcript regulation in Arabidopsis thaliana and the halotolerant Lobularia maritima indicates genes with potential function in plant salt adaptation. Gene 423, 142-148. http://dx.doi.org/10. 1016/j.gene.2008.07.017.

Pottosin, I., Shabala, S., 2014. Polyamines control of cation transport across plant membranes: implications for ion homeostasis and abiotic stress signaling. Front. Plant Sci. 5, 154. http://dx.doi.org/10.3389/fpls.2014.00154.

Raney, J., Reynolds, D., Elzinga, D., Page, J., Udall, J.A., Jellen, E.N., Bonfacio, A., Fairbanks, D.J., Maughan, P.J., 2014. Transcriptome analysis of drought induced stress in Chenopodium quinoa. Am. J. Plant Sci. 5, 338-357. http://dx.doi.org/10. 4236/ajps.2014.53047. http://www.scirp.org/journal/ajps.

Razzaghi, F., Ahmadi, S.H., Adolf, V.I., Jensen, C.R., Jacobsen, S.E., Andersen, M.N., 2011. Water relations and transpiration of quinoa (Chenopodium quinoa Willd.) under salinity and soil drying. J. Agron. Crop Sci. 197, 348-360. http://dx.doi.org/10. 1111/j.1439-037X.2011.00473.x.

Ruiz, K.B., Biondi, S., Oses, R., Acuña-Rodríguez, I.S., Antognoni, F., Martínez-Mosqueira, E.A., Coulibaly, A., Canahua-Murillo, A., Pinto, M., Zurita-Silva, A., Bazile, D., 2014 Quinoa biodiversity and sustainability for food security under climate change. A review. Agron. Sustain. Dev. 34, 349-359. http://dx.doi.org/10.1007/ s13593-013-0195-0.

Ruiz, K.B., Aloisi, I., Del Duca, S., Canelo, V., Torrigiani, P., Silva, H., Biondi, S., 2016a. Salares versus coastal ecotypes of quinoa: salinity responses in Chilean landraces from contrasting habitats. Plant Physiol. Biochem. 101, 1-13. http://dx.doi.org/10.1016/ j.plaphy.2016.01.010.

Ruiz, K.B., Biondi, S., Martínez, E.A., Orsini, F., Antognoni, F., Jacobsen, S.E., 2016b. Quinoa a model crop for understanding salt-tolerance mechanisms in halophytes. Plant Biosyst. 150, 357-371. http://dx.doi.org/10.1080/11263504.2015.1027317.

Ruiz-Carrasco, K., Antognoni, F., Coulibaly, A.K., Lizardi, S., Covarrubias, A., Martínez, E.A., Molina-Montenegro, M.A., Biondi, S., Zurita-Silva, A., 2011. Variation in salinity tolerance of four lowland genotypes of quinoa (Chenopodium quinoa Willd.) as assessed by growth, physiological traits, and sodium transporter gene expression. Plant Physiol. Biochem. 49, 1333-1341. http://dx.doi.org/10.1016/j.plaphy.2011. 08.005 .

Rus, A., Lee, B.H., Muñoz-Mayor, A., Sharkhuu, A., Miura, K., Zhu, J.K., Bressan, R.A., Hasegawa, P.M., 2004. AtHKT1 facilitates $\mathrm{Na}^{+}$homeostasis and $\mathrm{K}^{+}$nutrition in planta. Plant Physiol. 136, 2500-2511. http://dx.doi.org/10.1104/pp.104.042234.

Saha, J., Brauer, E. K., Sengupta, A., Popescu, S.C., Gupta, K., Gupta, B., 2015. Polyamine as redox homeostasis regulators during salt stress in plants. Front. Environ. Sci. 3, 21. http://dx.doi.org/10.3389/fenvs.2015.00021.

Sakuma, Y., Liu, Q., Dubouzet, J.G., Abe, H., Shinozaki, K., Yamaguchi-Shinozaki, K., 2002. DNA-binding specificity of the ERF/AP2 domain of Arabidopsis DREBs, transcription factors involved in dehydration- and cold-inducible gene expression. Biochem. Biophys. Res. Commun. 290, 998-1009. http://dx.doi.org/10.1006/bbrc. 2001.6299.

Sauter, A., Dietz, K.J., Hartung, W., 2002. A possible stress physiological role of abscisic acid conjugates in root-to-shoot signalling. Plant Cell Environ. 25, 223-228. http:// dx.doi.org/10.1046/j.1365-3040.2002.00747.x.

Scaramagli, S., Franceschetti, M., Michael, A.J., Torrigiani, P., Bagni, N., 1999. Polyamines and flowering: spermid ine biosynthesis in the different whorls of developing flowers of Nicotiana tabacum L. Plant Biosyst. 133, 229-237. http://dx. doi.org/10.1080/11263509909381554.

Shabala, S., Hariadi, Y., Jacobsen, S.E., 2013. Genotypic difference in salinity tolerance in quinoa is determined by differential control of xylem $\mathrm{Na}^{+}$loading and stomatal density. J. Plant Physiol. 170, 906-914. http://dx.doi.org/10.1016/j.jplph.2013.01. 014.

Shao, Q., Zhao, C., Han, N., Wang, B.S., 2008. Cloning and expression pattern of SsHKT1 encoding a putative cation transporter from halophyte Suaeda salsa. DNA Seq. 19, 106-114. http://dx.doi.org/10.1080/10425170701447465.

Shavrukov, Y., Zhumalin, A., Serikbay, D., Botayeva, M., Otemisova, A., Absattarova, A., 
Sereda, G., Sereda, S., Shvidchenko, V., Turbekova, A., Jatayev, S., Lopato, S., Soole, K., Langridge, P., 2016. Expression level of the DREB2-type gene, identified with Amplifluor SNP markers, correlates with performance, and tolerance to dehydration in bread wheat cultivars from northern Kazakhstan. Front. Plant Sci. 7, 1736. http:// dx.doi.org/10.3389/fpls.2016.01736.

Shi, H., Quintero, F.J., Pardo, J.M., Zhu, J.K., 2002. The putative plasma membrane $\mathrm{Na}^{+}$/ $\mathrm{H}^{+}$antiporter SOS1 controls long-distance $\mathrm{Na}^{+}$transport in plants. Plant Cell 14, 465-477. http://dx.doi.org/10.1105/tpc.010371.

Shinozaki, K., Yamaguchi-Shinozaki, K., 2007. Gene networks involved in drought stress response and tolerance. J. Exp. Bot. 58, 221-227. http://dx.doi.org/10.1093/jxb/ erl164.

Song, J., Wang, B., 2015. Using euhalophytes to understand salt tolerance and to develop saline agriculture: Suaeda salsa as a promising model. Ann. Bot. 115, 541-553. http://dx.doi.org/10.1093/aob/mcu194.

Strizhov, N., Ábrahám, E., Ökrész, L, Blickling, S., Zilberstein, A., Schell, J., Koncz, C., Szabados, L., 1997. Differential expression of two P5CS genes controlling proline accumulation during salt-stress requires ABA and is regulated by ABA1ABI1 and AXR2 in Arabidopsis. Plant J. 12, 557-569. http://dx. doi.org/10.1111/j.0960-7412. 1997.00557.x.

Sudhakar Reddy, P., Srinivas Reddy, D., Sivasakthi, K., Bhatnagar-Mathur, P., Vadez, V., Sharma, K.K., 2016. Evaluation of sorghum [Sorghum bicolor (L.)] reference genes in various tissues and under abiotic stress conditions for quantitative real-time PCR data normalization. Front. Plant Sci. 7, 529. http://dx.doi.org/10.3389/fpls.2016.00529.

Sun, X.B., Ma, H.X., Jia, X.P., Chen, Y., Ye, X.Q., 2015. Molecular cloning and characterization of two novel DREB genes encoding dehydration-responsive element binding proteins in halophyte Suaeda salsa. Genes Genom. 37, 199-212. http://dx. doi.org/10.1007/s13258-014-0238-1.

Szabados, L., Savouré, A., 2010. Proline: a multifunctional amino acid. Trends Plant Sci. 15, 89-97. http://dx.doi.org/10.1016/j.tplants.2009.11.009.

Taji, T., Seki, M., Satou, M., Sakurai, T., Kobayashi, M., Ishiyama, K., Narusaka, Y., Narusaka, M., Zhu, J.-K., Shinozaki, K., 2004. Comparative genomics in salt tolerance between Arabidopsis and Arabidopsis-related halophyte salt cress using Arabidopsis microarray. Plant Physiol. 135, 1697-1709. http://dx.doi.org/10.1104/pp.104. 039909. .

Trivellini, A., Lucchesini, M., Ferrante, A., Carmassi, G., Scatena, G., Vernieri, P. Mensuali-Sodi, A., 2016. Survive or die? A molecular insight into salt-dependant signaling network. Environ. Exp. Bot. 132, 140-153. http://dx.doi.org/10.1016/j. envexpbot.2016.07.007.

Vega-Gálvez, A., Miranda, M., Vergara, J., Uribe, E., Puente, L, Martínez, E.A., 2010. Nutrition facts and functional potential of quinoa (Chenopodium quinoa willd.), an ancient Andean grain: a review. J. Sci. Food Agric. 90, 2541-2547. http://dx.doi.org/ $10.1002 /$ jsfa. 4158
Wang, J., Meng, Y., Li, B., Ma, X., Lai, Y., Si, E., Yang, K., Xu, X., Shang, X., Wang, H., Wang, D., 2015. Physiological and proteomic analyses of salt stress response in the halophyte Halogeton glomeratus. Plant Cell Environ. 38, 655-669. http://dx.doi.org/ 10.1111/pce.12428.

Wen, X.P., Pang, X.M., Matsuda, N., Kita, M., Inoue, H., Hao, Y.J., Honda, C., Moriguchi, T., 2008. Over-expression of the apple spermidine synthase gene in pear confers multiple abiotic stress tolerance by altering polyamine titers. Trans. Res. 17, 251-263. http://dx.doi.org/10.1007/s11248-007-9098-7.

Willkinson, S., Davies, W.J., 2002. ABA-based chemical signalling: the coordination of responses to stress in plants. Plant Cell Environ. 25, 195-210. http://dx.doi.org/10. 1046/j.0016-8025.2001.00824.x.

Yadav, N.S., Shukla, P.S., Jha, A., Agarwal, P.K., Jha, B., 2012. The SbSOS1 gene from the extreme halophyte Salicomia brachiata enhances $\mathrm{Na}+$ loading in xylem and confers salt tolerance in transgenic tobacco. BMC Plant Biol. 12, 188. http://dx.doi.org/10. 1186/1471-2229-12-188.

Yamamoto, N., Takano, T., Tanaka, K., Ishige, T., Terashima, S., Endo, C., Kurusu, T., Yajima, S., Yano, K., Tada, Y., 2015. Comprehensive analysis of transcriptome response to salinity stress in the halophytic turf grass Sporobolus virginicus. Front. Plant Sci. 6, 241. http://dx.doi.org/10.3389/fpls.2015.00241.

Yang, O., Popova, O.V., Süthoff, U., Liiking, I., Dietz, K.J., Golldack, D., 2009. The Arabidopsis basic leucine zipper transcription factor AtbZIP24 regulates complex transcriptional networks involved in abiotic stress resistance. Gene 436, 45-55. http://dx.doi.org/10.1016/j.gene.2009.02.010.

Yasui, Y., Hirakawa, H., Oikawa, T., Toyoshima, M., Matsuzaki, C., Ueno, M., Mizuno, N., Nagatoshi, Y., Imamura, T., Miyago, M., Tanaka, K., 2016. Draft genome sequence of an inbred line of Chenopodium quinoa, an allotetraploid crop with great environmental adaptability and outstanding nutritional properties. DNA Res.. http:// dx.doi.org/10.1093/dnares/dsw037. p.dsw037.

Zhang, J., Jia, W., Yang, J., Ismail, A.M., 2006. Role of ABA in integrating plant responses to drought and salt stresses. Field Crops Res. 97, 111-119. http://dx.doi.org/10. 1016/j.fcr.2005.08.018.

Zhao, F.Y., Zhang, X.J., Li, P.H., Zhao, Y.X., Zhang, H., 2006. Co-expression of the Suaeda salsa SsNHX1 and Arabidopsis AVP1 confer greater salt tolerance to transgenic rice than the single SsNHX1. Mol. Breed. 17, 341-353. http://dx.doi.org/10.1007/ s11032-006-9005-6.

Zhao, M.R., Han, Y.Y., Feng, Y.N., Li, F., Wang, W., 2012. Expansins are involved in cell growth mediated by abscisic acid and indole-3-acetic acid under drought stress in wheat. Plant Cell Rep. 31, 671-685. http://dx.doi.org/10.1007/s00299-011-1185-9.

Zhao, L., Wang, P., Hou, H., Zhang, H., Wang, Y., Yan, S., Huang, Y., Li, H., Tan, J., Hu, A., Gao, F., 2014. Transcriptional regulation of cell cycle genes in response to abiotic stresses correlates with dynamic changes in histone modifications in maize. Plos One 9 (8), p.e106070. http://dx.doi.org/10.1371/journal.pone.0106070. 